\title{
A Spatial, Multivariable Approach for Identifying Proximate Sources of Escherichia coli to Maumee Bay, Lake Erie, Ohio
}

By Donna S. Francy, Pamela Struffolino, Amie M. G. Brady, and Daryl F. Dwyer

In cooperation with the Ohio Water Development Authority, Cities of Oregon and Toledo,

University of Toledo, and Toledo Metropolitan Area Council of Governments

Open-File Report 2005-1386

U.S. Department of the Interior

U.S. Geological Survey 


\section{U.S. Department of the Interior \\ Gale A. Norton, Secretary}

\section{U.S. Geological Survey \\ P. Patrick Leahy, Acting Director}

U.S. Geological Survey, Reston, Virginia: 2005

For sale by U.S. Geological Survey, Information Services

Box 25286, Denver Federal Center

Denver, CO 80225

For more information about the USGS and its products:

Telephone: 1-888-ASK-USGS

World Wide Web: http://www.usgs.gov/

\footnotetext{
Any use of trade, product, or firm names in this publication is for descriptive purposes only and does not imply endorsement by the U.S. Government.

Although this report is in the public domain, permission must be secured from the individual copyright owners to reproduce any copyrighted materials contained within this report.
} 


\section{Contents}

Abstract

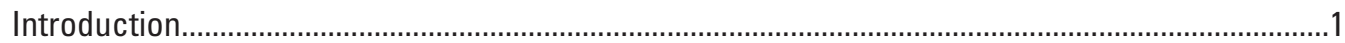

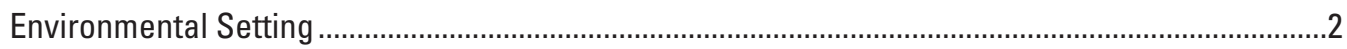

Methods of Study

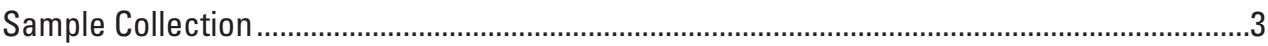

Analysis of Water and Bed-Sediment Samples..................................................................

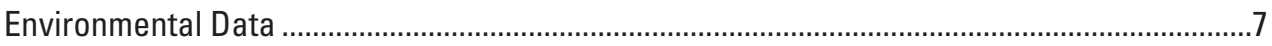

Concentrations of E. coli in Water and Bed Sediments During Synoptic Studies ............................7

Phase 1, Spatial Survey .......................................................................................................

Phase 2, Intensive Sampling at Fecal Contaminant "Hot Spots" ............................................8

Relations of Water-Quality or Environmental Variables to E. coli Concentrations at Maumee Bay State Park During Routine Monitoring.......................................................10

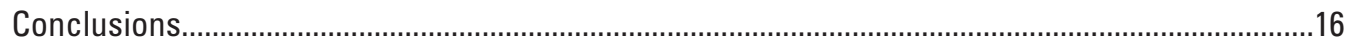

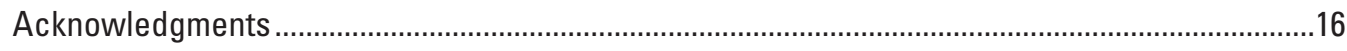

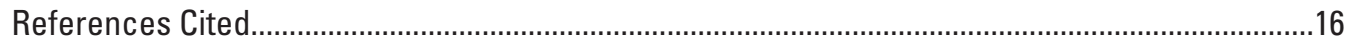

Appendixes:

1. Locations of sampling sites, Maumee Bay, Ohio, 2003 and 2004 .....................................18

2. Concentrations of Escherchia coli (E. coli) in water and bed sediments, 2003..................19

3. Concentrations of Escherchia coli (E. coli) in water and bed sediments, 2004...................20

\section{Figures}

1. Map showing the study area and sampling sites, Maumee Bay, Lake Erie, Ohio ................3

2. Photographs showing scenes from the study area ........................................................

3. Map showing average E. coli concentrations in Maumee Bay area, phase 1 (2003) ..........5

4. Map showing average $E$. coli concentrations in Maumee Bay area, phase 2 (2004) .........6

5. Photographs showing sediment-sampling techniques ...........................................................

6-12. Graphs showing-

6. Relation between weighted particle-size index and average E. coli concentration at 24 sites, phase 1 (2003)

7. Relation between water depth and concentrations of $E$. coli in bed-sediment samples, phase 1 (2003) ..........................................................................................

8. Concentrations of $E$. coli in water and bed sediments and water temperatures in the intake to and outfall from the powerplant, phase 1 (2003)

9. Concentrations of E. coli in downstream order at Maumee River sites and increasing distance offshore from the mouth of the Maumee River, phase 2 (2004), in water and bed sediments

10. Concentrations of $E$. coli at sites in and around Berger Ditch (N14), phase 2 (2004), in water and sediments

11. Concentrations of $E$. coli at Maumee Bay State Park as a function of wind direction at the time of sampling, 2003 and 2004

12. Concentrations of E. coli at Maumee Bay State Park based on wave height at the time of sampling, 2003 and 2004 


\section{Table}

1. Pearson's $r$ correlations between log E. coli concentrations in water at Maumee Bay State Park and environmental or water-quality factors, 2003 and 2004.

\section{Conversion Factors and Abbreviations}

\begin{tabular}{lcl}
\hline \multicolumn{1}{c}{ Multiply } & By & \multicolumn{1}{c}{ To obtain } \\
\hline & Length & \\
\hline centimeter $(\mathrm{cm})$ & 0.3937 & inch (in.) \\
millimeter $(\mathrm{mm})$ & 0.03937 & inch (in.) \\
meter $(\mathrm{m})$ & 3.281 & foot $(\mathrm{ft})$ \\
kilometer $(\mathrm{km})$ & 0.6214 & mile $(\mathrm{mi})$ \\
\hline & Area & \\
\hline square kilometer $\left(\mathrm{km}^{2}\right)$ & 0.3861 & square mile $\left(\mathrm{mi}^{2}\right)$ \\
\hline & Volume & \\
\hline milliliter $(\mathrm{mL})$ & 0.06102 & cubic inch $\left(\mathrm{in}^{3}\right)$ \\
\hline & Mass & \\
\hline gram $(\mathrm{g})$ & 0.03527 & ounce, avoirdupois $(\mathrm{oz})$ \\
\hline
\end{tabular}

Temperature in degrees Celsius $\left({ }^{\circ} \mathrm{C}\right)$ may be converted to degrees Fahrenheit $\left({ }^{\circ} \mathrm{F}\right)$ as follows:

$$
{ }^{\circ} \mathrm{F}=\left(1.8 \mathrm{x}^{\circ} \mathrm{C}\right)+32
$$

Turbidity is reported in Nephelometric Turbidity Units (NTU).

Concentrations of bacteria in water are reported in colonies per 100 milliliters (col/100 mL) or most probable number per 100 milliliters (MPN/100 mL)

Concentrations of bacteria in sediment are reported in most probable number per gram dry weight of sediment (MPN $/ \mathrm{g}_{\mathrm{DW}}$ ).

Concentrations that are less than a specified value are reported as $<$, greater than are reported as $>$, less than or equal to are reported as $\leq$, and greater than or equal to are reported as $\geq$. 


\title{
A Spatial, Multivariable Approach for Identifying Proximate Sources of Escherichia coli to Maumee Bay, Lake Erie, Ohio
}

\author{
By Donna S. Francy, Pamela Struffolino', Amie M. G. Brady, and Daryl F. Dwyer ${ }^{1}$
}

\section{ABSTRACT}

Sources of $E$. coli at U.S. beaches are often unknown. Determining the spatial distribution of $E$. coli and identifying factors that can affect concentrations may provide insight into the sources of fecal contamination. This approach was used to investigate a popular bathing beach in northwest Ohio-Maumee Bay State Park (MBSP). In 2003 synoptic studies, water and bed-sediment samples were collected and analyzed for E. coli at 24 sites within Maumee Bay, a nearby shipping channel, a major tributary to the bay (Maumee River), and nearshore areas at the mouths of drainage ditches. In 2004, samples were collected at 22 sites identified as "hot spots" of fecal contamination during 2003. Daily samples for E. coli were collected at MBSP as part of the Ohio Bathing Beach Monitoring Program. Highest E. coli concentrations were found at sites in the Maumee River, the shipping channel, and in or at the mouth of some drainage ditches. These high values were found in bed sediments underlying the deepest waters, which may act as an E. coli sink. Low E. coli concentrations at sites remote to MBSP indicated that sources from these areas were not important contributors of $E$. coli. Temperature changes in discharge from a local powerplant did not cause an increase in E. coli concentrations. A ditch that discharges 75 $\mathrm{m}$ east of the bathing beach was shown to be a principal source of $E$. coli. Turbidity and rainfall were positively correlated with E. coli concentrations at MBSP. Higher wave heights and wind directions from the north, northeast, or northwest were associated with higher $E$. coli concentrations.

\section{Introduction}

To protect the health of visitors, managers of beach recreational areas issue advisories or closings on the basis of standards for concentrations of bacterial indicator organisms. For freshwater beaches, Escherichia coli (E. coli) is the indicator most commonly used to assess recreational water quality. In spite of increased focus on beach water-quality issues and

\footnotetext{
${ }^{1}$ University of Toledo.
}

the passage of the Federal Beaches Environmental Assessment and Coastal Health Act of 2000 (U.S. Congress, 2000), many U.S. beaches continue to be plagued with high bacterial indicator concentrations. Beaches are better monitored than they were in the past, but the sources of fecal contamination that trigger most closings and advisories remain unknown. For example, in 2003, unknown sources of contamination caused approximately 12,000 closings and advisories in the U.S. - 68 percent of the year's total for the nation (Natural Resources Defense Council, 2004). Possible sources of contamination include combined and sanitary-sewer overflows; treated wastewater effluents; sewage from private sewage-treatment systems, including septic tanks; fecal pollution from birds, swimmers, or boats; and stormwater runoff. Identifying and mitigating the source of fecal contamination to a particular beach is often complicated by the spatial and temporal variability of bacterial indicator concentrations and the dynamic lake currents, weather patterns, and natural processes that affect these concentrations.

Determining the spatial distribution of E. coli in bed sediments throughout an affected area may help identify proximate sources of fecal contamination. Bacteria have been shown to survive longer in sediments than in water (LaLiberte and Grimes, 1982; Burton and others, 1987); therefore, resuspension of $E$. coli from bed sediments, either by dredging or by natural causes, may affect recreational water quality. Evidence for short-term storage (less than a week) of E. coli in lake-bottom sediments was found at a Lake Erie bathing beach (Francy and Darner, 1998). In a study of a Lake Michigan beach, bed sediments from a nearby creek were a principal source of $E$. coli affecting recreational water quality (Byappanahalli and others, 2003). In a study of recreational marine beaches in California, the spatial and temporal distribution of indicator bacteria in bed sediments and the overlying water column led to the conclusion that contaminant sources were from inside the bay and the land side of the beach (Boehm and others, 2003).

Similarly, identifying relevant environmental and waterquality factors, such as wind direction, rainfall, and turbidityall of which can affect $E$. coli concentrations-also may help 
in identifying sources. In a recent study, investigators found that wave height and rainfall affected $E$. coli concentrations at all five Lake Erie beaches tested, but number of birds and current direction affected $E$. coli at only a few of the beaches (Francy and others, 2003). At one of four estuary beaches on Long Island Sound, investigators were unable to relate high enterococci counts to antecedent rainfall. They later found that the cause of contamination was the illegal disposal of boat wastes at a nearby marina (City of Stamford, 2001).

The U.S. Geological Survey, in cooperation with the Ohio Water Development Authority, Cities of Oregon and Toledo, University of Toledo, and Toledo Metropolitan Area Council of Governments, examined spatial and environmental factors in combination to identify sources of fecal contamination near a popular bathing beach in Maumee Bay in northwest Ohio. This report describes how information on spatial patterns of $E$. coli in bed sediments and water led to identifying fecalcontaminant "hot spots" in a study area. Relations between environmental and water-quality factors and E. coli concentrations at the bathing beach were used to help corroborate results from spatial studies. This study illustrates how to take first steps towards identifying sources of fecal contamination in an urbanized and hydrologically complicated area with numerous potential sources. Identifying proximate sources enables local water-resource managers to apply more sophisticated sourcetracking tools to identify specific sources of fecal contamination and, ultimately, take appropriate mitigation measures.

\section{Environmental Setting}

Maumee Bay, in the southwest corner of Lake Erie, borders the cities of Toledo and Oregon (fig. 1). Maumee Bay is a popular recreational destination in Ohio for swimming, boating, fishing, and observing wildlife. In particular, Maumee Bay State Park (MBSP) is recognized as a major attraction in the area and has two swimming beaches-one along the Lake Erie shoreline (fig. 2a) and one inland. The Lake Erie beach is often impaired by high $E$. coli concentrations. If the concentration of $E$. coli exceeds the 5-day geometric mean standard of 126 colonies per 100 milliliters (col/100 mL) established by the State of Ohio (Ohio Environmental Protection Agency, 2002), beach managers at MBSP post a beach advisory. The Lake Erie beach was posted with water-quality advisories on 29 days in 2001, 8 days during 2002, 44 days during 2003, and 20 days during 2004 (Ohio Department of Health, 2004). In addition, waters at other unmonitored locations in Maumee Bay may be unsafe for primary- and secondary-contact recreation, such as boating and swimming.

MBSP is just east of an urbanized and hydrologically complicated area (fig. 1). The Ottawa River drains into northwest Maumee Bay and has a drainage area of $388 \mathrm{~km}^{2}$ at the USGS streamflow-gaging station $17.5 \mathrm{~km}$ upstream from the mouth. The Maumee River at its mouth at Toledo has a drainage area of $17,114 \mathrm{~km}^{2}$ (Shindel and others, 2002), the largest of any Great Lakes tributary (fig. 2b). The City of Toledo's wastewater-treatment plant discharges effluent into the river approximately $2.1 \mathrm{~km}$ upstream from the mouth. The Port of Toledo, at the mouth of the Maumee River, is one of the busiest ports in the Great Lakes. The U.S. Army Corps of Engineers maintains a navigable depth of approximately 8.5 $\mathrm{m}$ in a shipping channel that extends $30.6 \mathrm{~km}$ offshore (Great Lakes Dredging Team, 1999). Water depths in Maumee Bay are among the shallowest in the Great Lakes; except for the dredged shipping channel, water depths in Maumee Bay are less than $3 \mathrm{~m}$. An inlet to a channel that feeds the intake of a powerplant is also near the mouth of the Maumee River. The powerplant uses water for cooling and discharges water into Maumee Bay that is warmer than the intake water. The Combined Disposal Facility and Grassy Island are two manmade structures built of dredged materials. The City of Oregon's wastewater-treatment plant discharges treated effluent $50 \mathrm{~m}$ offshore of the southern side of the Combined Disposal Facility (fig. 2c). Eastward along the Maumee Bay shoreline, drainage ditches were built to drain an area that was formerly swamp and wetlands and is now urban, agricultural, and industrial.

Potential sources of fecal contamination to Maumee Bay and MBSP are numerous. The Maumee River receives inputs from combined sewer overflows (CSOs) and stormwater runoff in Toledo. Inputs upstream from Toledo include runoff from row-crop and animal agricultural activities, septic-tank effluent, and runoff and wastewater effluent from towns and cities. Elevated temperatures from heated effluent from the nearby powerplant could potentially enhance the growth of E. coli. Elevated E. coli concentrations may also be due to conveyance of fecal contamination from septic tanks, farm fields, or wildlife via drainage ditches. Of particular concern is Berger Ditch, which discharges at the marina at MBSP, $75 \mathrm{~m}$ east of the bathing beach (figs. $2 \mathrm{~d}$ and $2 \mathrm{e}$, site N10). In previous work, high $E$. coli concentrations were consistently found in bed sediments and waters of Berger Ditch (Glatzer and Erichsen, 2003).

\section{Methods of Study}

Two types of field studies - synoptic studies and routine monitoring - were done during the recreational seasons (May through September) of 2003 and 2004. Synoptic studies were done in two phases with six field trips in each phase. In phase 1 (2003), water and bed-sediment samples were collected at sites that were selected to ensure good spatial coverage of the study area and that were near possible sources of fecal contamination (fig. 3). Sampling locations included nearshore sites in Maumee Bay and the lower Ottawa River (N), offshore sites within Maumee Bay (O), and sites in the lower Maumee River (M). In 2003, sampling was done at 24 sites on June 24-25, July 29, July 30, September 7, and September 11; a subset of 8 sites was sampled on August 14, 2003. 


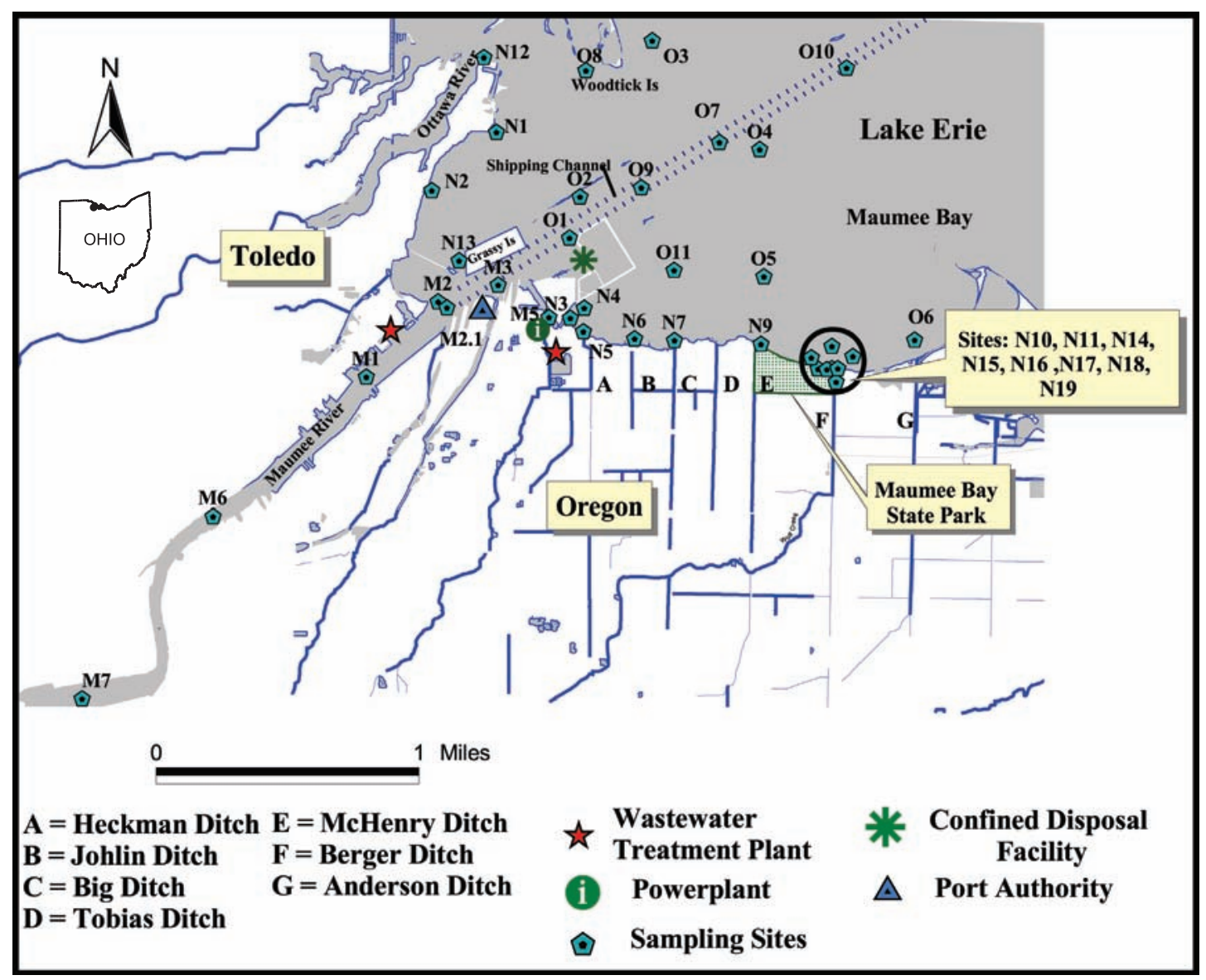

Figure 1. Study area and sampling sites, Maumee Bay, Lake Erie, Ohio.

In phase 2 (2004), sampling sites shown in phase 1 to have elevated $E$. coli concentrations were selected for further, intensive study. During phase 2, water and bed-sediment samples were collected at these fecal contaminant "hot spots" (fig. 4). In 2004, samples were collected from 22 sites on May 12, June 15, July 13, August 16, and August 17; a subset of 9 sites was sampled on March 24 and 27. The locations of synoptic sampling sites during both recreational seasons are listed in Appendix 1. For routine monitoring in 2003 and 2004, a daily water sample for $E$. coli was collected Monday through Thursday at MBSP as part of the Ohio Department of Health's bathing beach monitoring program (Ohio Department of Health, 2004).

\section{Sample Collection}

Two sampling crews were used during phase 1 and phase 2 synoptic studies, enabling sampling to be done between 9:00 a.m. and 2:30 p.m. One crew used a 7.7-m center console boat ("large boat") to collect samples at Maumee River and offshore sites. A second crew used a jon boat or waded to nearshore sites. For routine monitoring, water samples were collected by the Ohio Department of Health between 12:00 and 1:30 p.m. where the water was $1 \mathrm{~m}$ deep in an area of the beach used for swimming. All water-sample bottles were filled about $0.3 \mathrm{~m}$ below the water surface using a grab-sampling technique.

During synoptic studies, field crews used special procedures to collect bed sediments. From the large boat, the field crew lowered a clean and sterile Petite Ponar Grab sampler (Wildlife Supply Company, Buffalo, N.Y.) through the water column and collected a sediment sample per the manufacturer's instructions. After it was brought to the surface, the sampler was drained of excess water, and the sediment was deposited into a clean and sterile washtub (fig. 5a). Two more bed-sediment subsamples were collected from the same location in this manner. Using a sterile spatula, the field crew composited three sediment subsamples in the washtub into a 250-mL labeled, sterile jar and immediately placed the jar in a cooler on ice. After excess sediment was brushed from the sampler, the sampler was decontaminated between sites as follows: (1) brush with dilute soap, (2) rinse with tap water, (3) soak in 0.005 percent bleach solution for 10 to 20 minutes, and (4) soak in 0.005 percent sodium thiosulfate solution for 5 minutes. From the jon boat, bed sediment was collected by diving or wading (fig. 5b). The diver secured the lid on a 


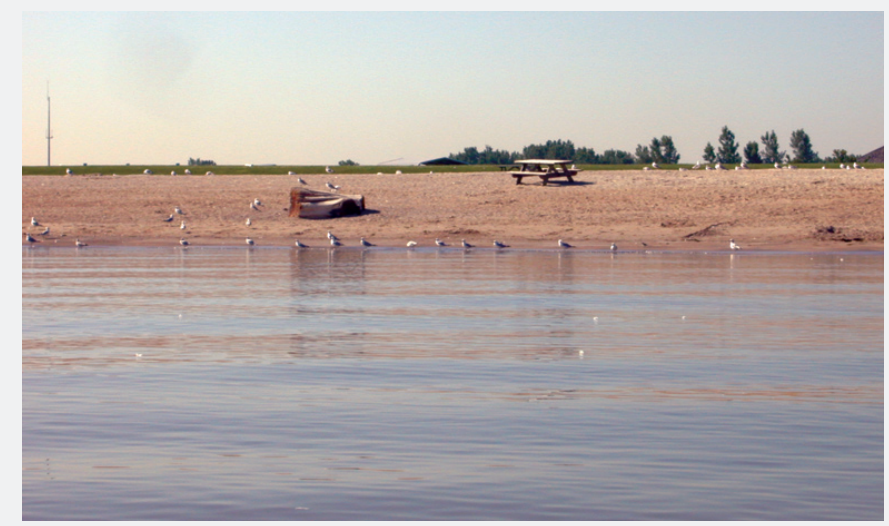

$\boldsymbol{A}$

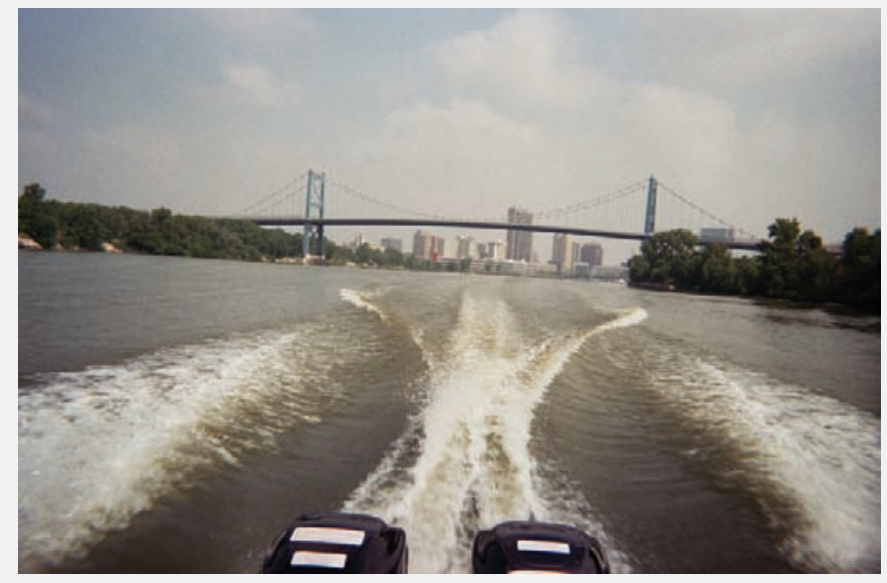

B

Photograph by John Tertuliani, U.S. Geological Survey

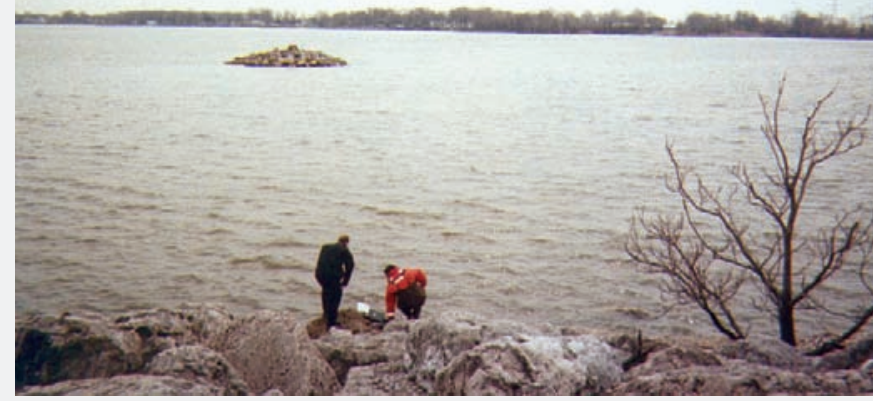

C
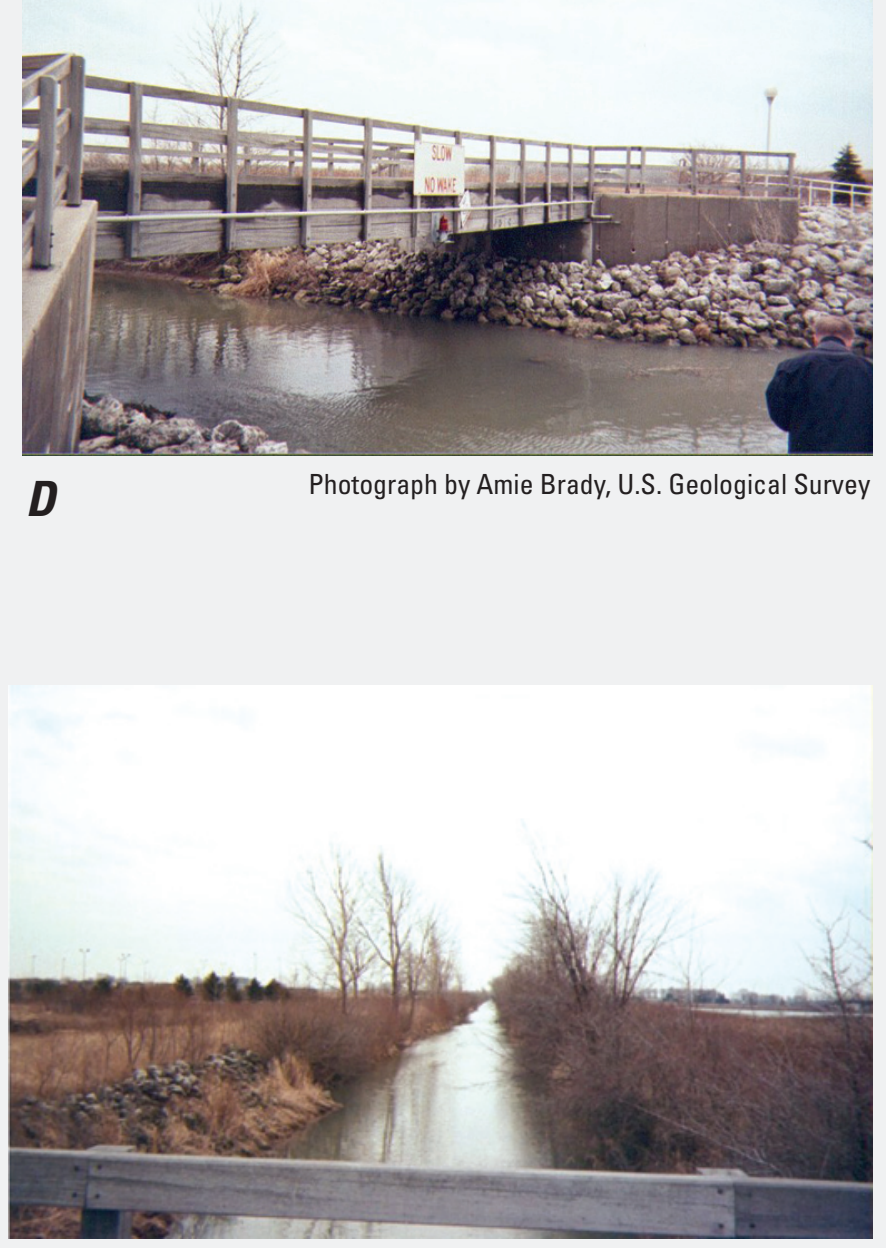

$\boldsymbol{E}$

Photograph by Amie Brady, U.S. Geological Survey

Figure 2. Scenes from the study area. $A$, Lake Erie beach at Maumee Bay State Park (looking south). $B$, Maumee River and downtown Toledo, upstream from the mouth between sampling sites M6 and M7 (looking southwest). C, Maumee Bay from the southern side of the Combined Disposal Facility at site N4 (looking southeast). $D$, Berger Ditch near the mouth and sampling site N14 (looking west). E, Berger Ditch, upstream from the mouth (looking south). 


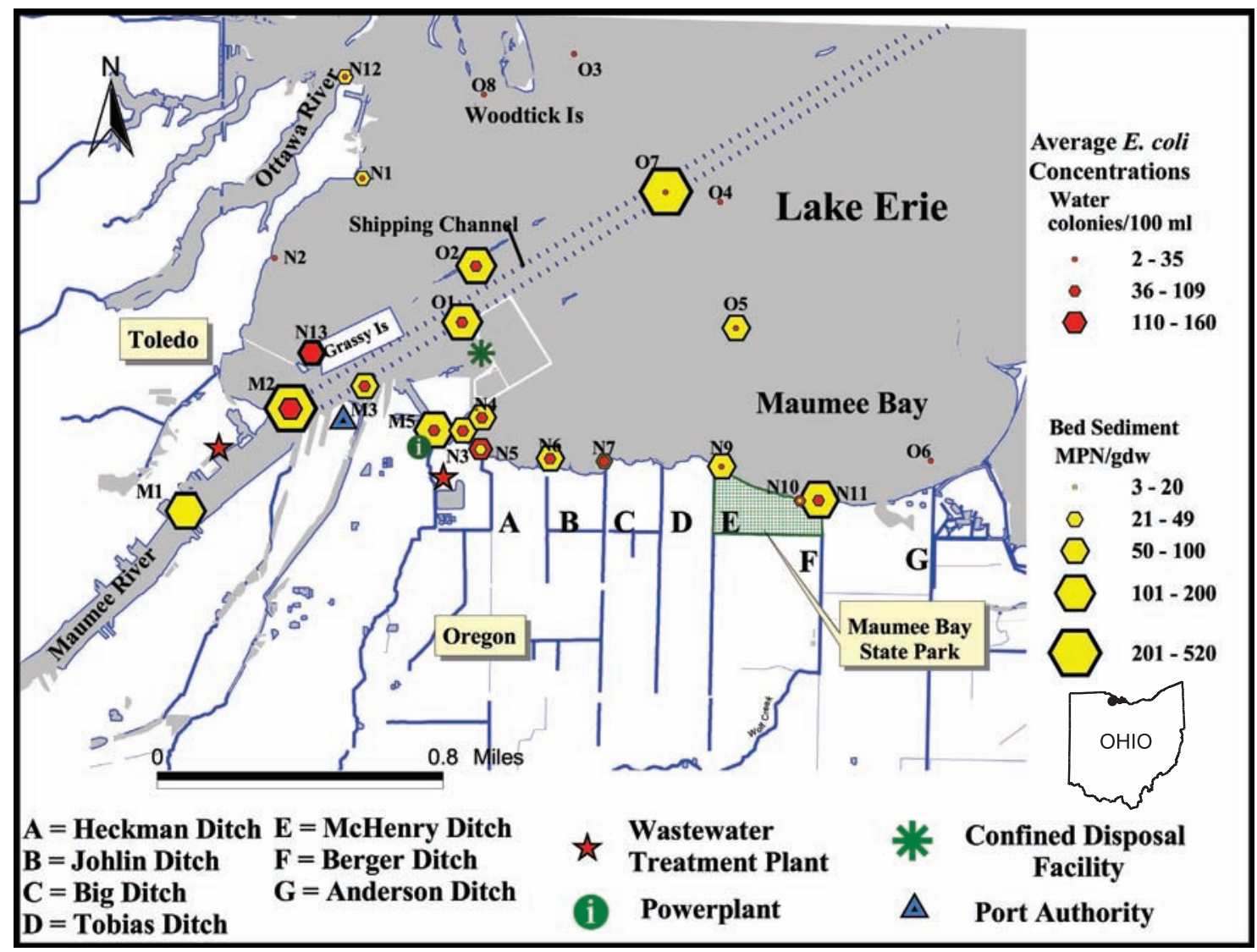

Figure 3. Average E. coli concentrations in Maumee Bay area, phase 1 (2003). Samples were collected during the recreational season (May through September) from 24 sites on 5 or 6 occasions at nearshore $(\mathrm{N})$, offshore $(0)$, and Maumee River (M) sites.

sterile 125- or 250-mL labeled sampling jar, dove to the lake bottom, opened the lid upon reaching the bottom, scooped the bottom sediments to obtain a sample, and closed the jar before surfacing. Two more subsamples were collected at each location in this manner and composited in the laboratory.

\section{Analysis of Water and Bed-Sediment Samples}

During phase 1 and 2 synoptic studies, water samples were analyzed for concentrations of E. coli within 6 hours of collection at the Lake Erie Center Laboratory, Oregon, Ohio, using the modified mTEC membrane-filtration method (U.S. Environmental Protection Agency, 2002). Bed-sediment samples were analyzed for concentrations of $E$. coli within 24 hours of collection at the USGS Ohio Water Microbiology Laboratory in Columbus, Ohio, by use of the Colilert Quantitray method (Idexx Laboratories, Westbrook, Maine). Sample-processing steps for sediment samples developed during an earlier study (Francy and Darner, 1998) were required before analysis. In summary, a $20 \mathrm{~g}$ aliquot of composited sediment from the three subsamples was placed into a bottle containing $200 \mathrm{~mL}$ of saline buffer; a second aliquot of composited sediment was reserved to determine percent dry weight. The bottle was placed on a shaker for 45 minutes, then removed; suspended materials were allowed to settle for 30 seconds, and the liquid phase was decanted for analysis. Calculations were made (Francy and Darner, 1998) to convert most probable number (MPN) counts to MPN per gram of dry weight sediment $\left(\mathrm{MPN} / \mathrm{g}_{\mathrm{DW}}\right)$. For routine monitoring, water samples were analyzed for concentrations of E. coli within 6 hours of collection at the City of Toledo Water Plant using the Colilert Quantitray method. Turbidity was determined in routine-monitoring water samples with a Hach Model 2100AN turbidimeter (Hach Company, 1989).

During phase 1, a bed-sediment sample from each site was analyzed for particle-size distribution at the USGS Sediment Laboratory in Louisville, Ky. This determination consisted of a sand/fine separation and a five-point fine analysis. For the sand/fine analysis, the composited sediment was processed through a wet sieve, dried, and weighed to determine the percentage of sediment finer than $0.062 \mathrm{~mm}$ (Guy, 1969). The fines were captured and allowed to settle for $2-3$ weeks. The water was decanted, and using the pipet method, the fractions finer than $0.002,0.004,0.008,0.016$, and 0.031 

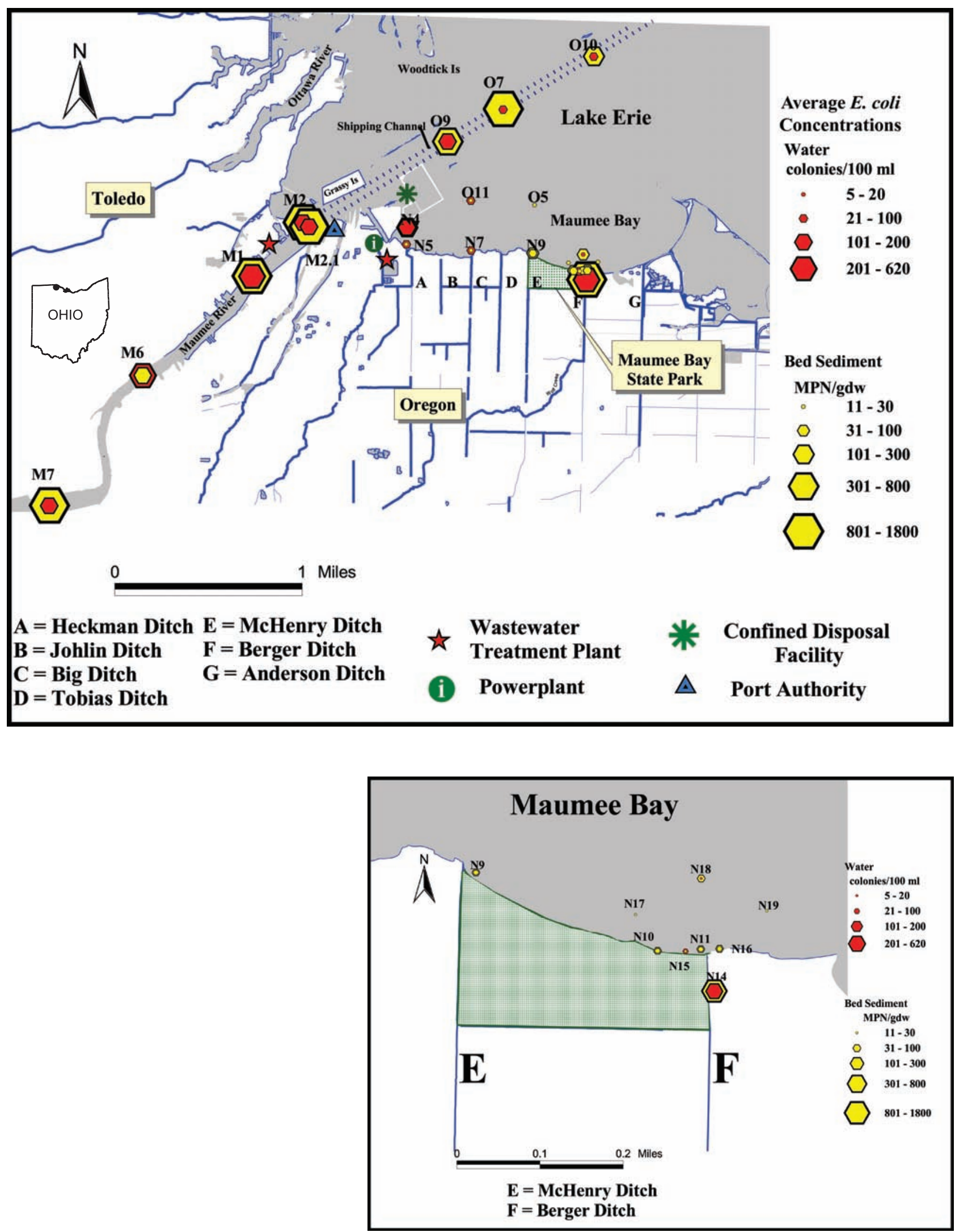

Figure 4. Average E. coli concentrations in Maumee Bay area, phase 2 (2004). Samples were collected from 22 sites during the recreational season (May through September) on 5 occasions at nearshore (N), offshore (0), and Maumee River (M) sites. 

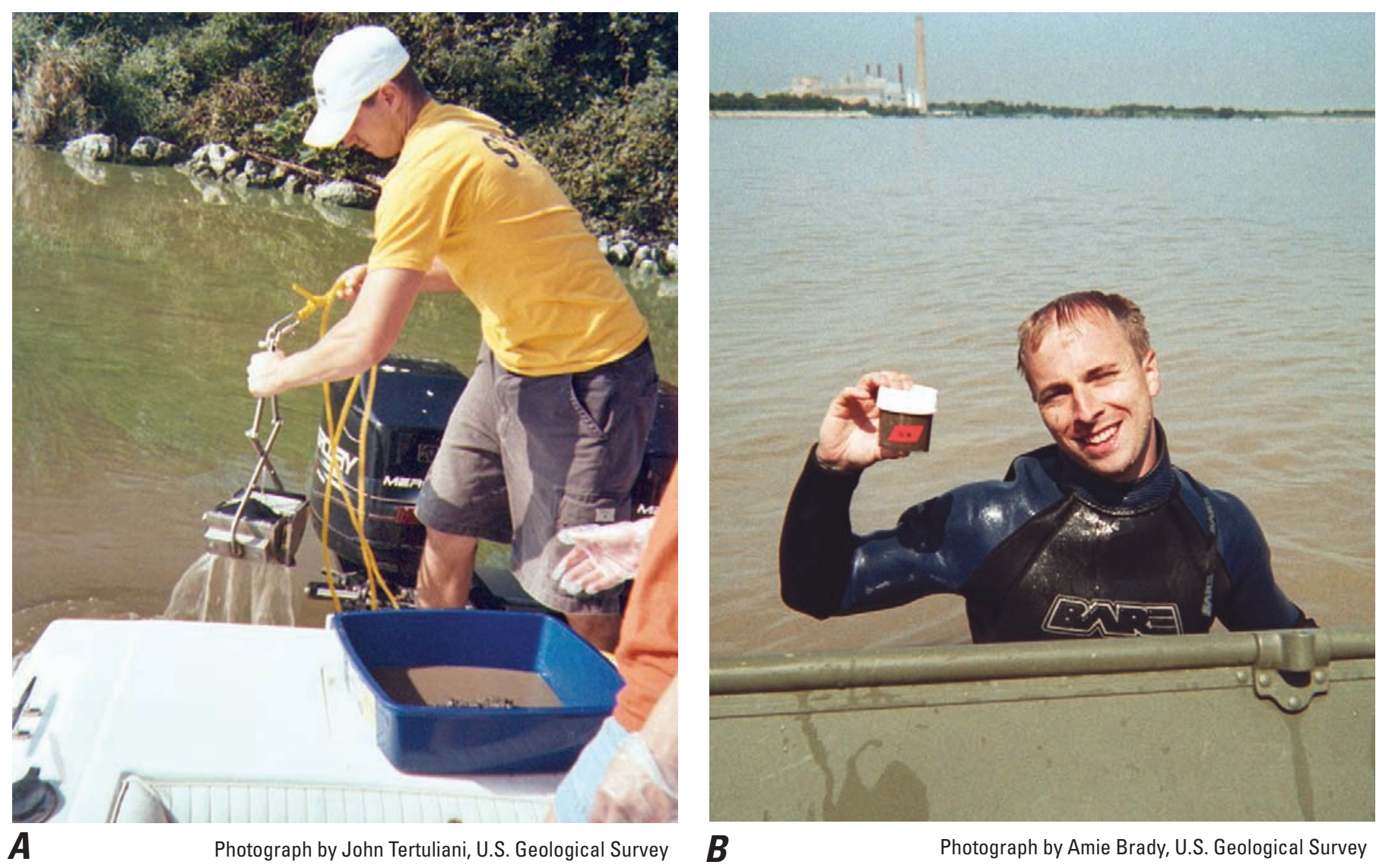

Figure 5. Sediment sampling techniques. $A$, To collect a bed-sediment sample, the field crew used a sterile Petite Ponar Grab sampler and deposited three subsamples into a clean and sterile washtub. $B$, When feasible, bed sediment was collected into three sterile 125or $250-\mathrm{mL}$ sampling jars at the site by diving or wading.

mm were determined (Guy, 1969). The percentages of particles in each size classification (clay, silt, and sand) were calculated by means of a computer program that uses available data and interpolates results (Stevens and Hubbell, 1986). Weighted values for particle size were calculated as follows: Weighted particle-size index $=$ (percent clay) $+2 \mathrm{x}$ (percent silt) $+3 \times$ (percent sand). Samples were classified into one of four categories on the basis of their index values: 125 to 166 , fine ( $>50$ percent clay); 182 to 205 , medium fine; 230 to 260 , medium coarse ( $>50$ percent sand); 261 to 300 , coarse ( $>90$ percent sand).

\section{Environmental Data}

Ancillary environmental data were collected by field crews or compiled from a variety of sources. In synoptic studies, field crews located sampling sites using a global positioning system and measured water depths using a fathometer. In routine monitoring, field personnel estimated wave heights and number of birds and bathers at the time of sample collection. Data from the USGS-operated streamflow-gaging station at the Maumee River at Waterville (USGS station 04193500) were used to estimate streamflow (Shindel and others, 2004, 2005).

Daily weather data were compiled from several agencies. Daily rainfall amounts and wind speed and direction data were obtained from the National Weather Service station at Toledo Metcalf Field (National Oceanic and Atmospheric Administration, 2004a), $16 \mathrm{~km}$ south of Maumee Bay. Daily weather data were also measured by the City of Oregon at the wastewater-treatment plant, about $1.5 \mathrm{~km}$ inland from the bay. Water-level data were obtained from a NOAA-operated station near the mouth of the Maumee River in Toledo, Ohio (NOAA ID 90663085; National Oceanic and Atmospheric Administration, 2004b). 


\section{Concentrations of $E$. coli in Water and Bed Sediments During Synoptic Studies}

\section{Phase 1, Spatial Survey}

The magnitudes of average $E$. coli concentrations from phase 1 synoptic surveys at 24 sites ( 16 sites sampled 5 times and 8 sites sampled 6 times) are represented by the size of the red and yellow octagons for water and bed sediments, respectively (fig. 3). Average E. coli concentrations (instead of medians) were used so that the influence from extreme measurements would be well represented. The individual measurements for each site and associated averages and standard deviations are listed in Appendix 2. In water, average E. coli concentrations ranged from 2 to $161 \mathrm{col} / 100 \mathrm{~mL}$.

E. coli concentrations in water were highest at Maumee River sites (M1 and M2) and at nearshore sites near the mouth of the Maumee River (N13 and N5). They were lowest at offshore sites $(\mathrm{O} 3, \mathrm{O} 4, \mathrm{O} 5, \mathrm{O} 6, \mathrm{O} 7, \mathrm{O} 8)$ and nearshore sites by Toledo (N1, N2, and N12) and west of MBSP (N9). Average E. coli concentrations in bed sediments ranged from 3 to 520 $\mathrm{MPN} / \mathrm{g}_{\mathrm{DW}}$. The two highest average $E$. coli concentrations in bed sediments were at sites in the Maumee River (M2) and the shipping channel (O7). Bed-sediment E. coli concentrations were also elevated at the mouth of Berger Ditch (N11) as compared to other sites in the vicinity (N9, N10, O6).

Phase 1 data can be used to examine the relations between particle size, water depth, and E. coli concentrations in the study area. Figure 6 shows the relation between weighted particle-size index and average $E$. coli concentration at each site, with key sites labeled. Although the sites with the highest average $E$. coli concentrations were associated with fine bed sediments ( $\mathrm{O} 7$ and $\mathrm{M} 2$ ), this was not true for every site. For example, at site N11, bed sediments were coarse, yet average $E$. coli concentration was elevated. At the other end, at site M3, bed sediments were fine, yet average $E$. coli concentration was low. Water depths at sampling points ranged from 0.3 to $9.6 \mathrm{~m}$ (fig. 7) with a median of $1.2 \mathrm{~m}$. E. coli concentrations in bed sediments in shallow waters less than $1.5 \mathrm{~m}$ deep ranged from $<1$ to $660 \mathrm{MPN} / \mathrm{g}_{\mathrm{DW}}$, and many were $<50 \mathrm{MPN} / \mathrm{g}_{\mathrm{DW}}$. In contrast, samples collected where waters were greater than $3 \mathrm{~m}$ deep had $E$. coli concentrations from 50 to $1,900 \mathrm{MPN} / \mathrm{g}_{\mathrm{DW}}$, and no samples were $<50 \mathrm{MPN} / \mathrm{g}_{\mathrm{DW}}$. All samples from water depths greater than $3 \mathrm{~m}$ were collected from Maumee River or shipping-channel sites; these were the sites where bed sediments were fine.

Concentrations of $E$. coli in water and bed sediments and water temperatures between the intake (M5) and outfall (N3) of the powerplant were examined (fig. 8). Although temperatures were higher in the outfall waters (median $=25.8^{\circ} \mathrm{C}$ ) than intake waters (median $\left.=22.7^{\circ} \mathrm{C}\right)$, E. coli concentrations in water and bed sediments were not higher at the outfall than at the intake. In fact, the median bed-sediment $E$. coli concentration was lower at the powerplant outfall $\left(36 \mathrm{MPN} / \mathrm{g}_{\mathrm{DW}}\right)$ than at the intake ( $\left.99 \mathrm{MPN} / \mathrm{g}_{\mathrm{DW}}\right)$.

During Phase 1, the fecal contaminant "hot spots" were identified as Maumee River sites, nearshore sites near the river and the mouth of Berger Ditch, and sites in the shipping channel. Low E. coli concentrations found at sites north and west of the shipping channel indicated that remote sources were not important contributors of E. coli. Similarly, low E. coli concentrations at nearshore sites west of MBSP indicated that westerly nearshore sources were not causing elevated concentrations at MBSP. Although higher E. coli concentrations in bed sediments were generally associated with finer sediment particles, several outliers were found; this may be because the presence or absence of a contaminant source has more influence on the $E$. coli concentration than the particle size of bed sediments. Elevated E. coli concentrations ( $50 \mathrm{MPN} / \mathrm{g}_{\text {DW }}$ ) were consistently found in bed sediments underlying the deepest waters; this was especially true of the shipping channel, which may act as a sediment/E. coli sink. The results indicate that temperature changes from the powerplant did not cause an increase in E. coli concentrations.

\section{Phase 2, Intensive Sampling at Fecal Contaminant "Hot Spots"}

On the basis of phase 1 results, phase 2 sampling locations were selected as follows (fig. 4):

- Maumee River sites upstream from phase 1 site M2 (M6 and M7) were added to evaluate potential upstream sources.

- A second site at the mouth of the Maumee River (M2.1) was added to compare a deeper site in the shipping channel to a phase 1 shallow sampling site outside the main channel (M2).

- Two additional shipping-channel sites (O9 and O10) flanking the phase 1 site $(\mathrm{O} 7)$ were added to further evaluate the shipping channel as an E. coli sink.

- An additional site between the shipping channel and MBSP (O11) was added to evaluate transport of $E$. coli from the shipping channel to the bathing beach.

- Additional sites in Berger Ditch (N14) and surrounding the mouth of Berger Ditch (N15, N16, N17, and N18) were added to augment data collected at sites N10 and $\mathrm{N} 11$ and evaluate Berger Ditch as a source of $E$. coli to MBSP.

Data collected during the phase 2 recreational season (fig. 4) corroborate the findings during phase 1 . During phase 2 , the highest average $E$. coli concentrations in water were found at Maumee River sites and in Berger Ditch. For sediments, average $E$. coli concentrations were highest in the Maumee River, shipping channel, and Berger Ditch. The individual mea- 


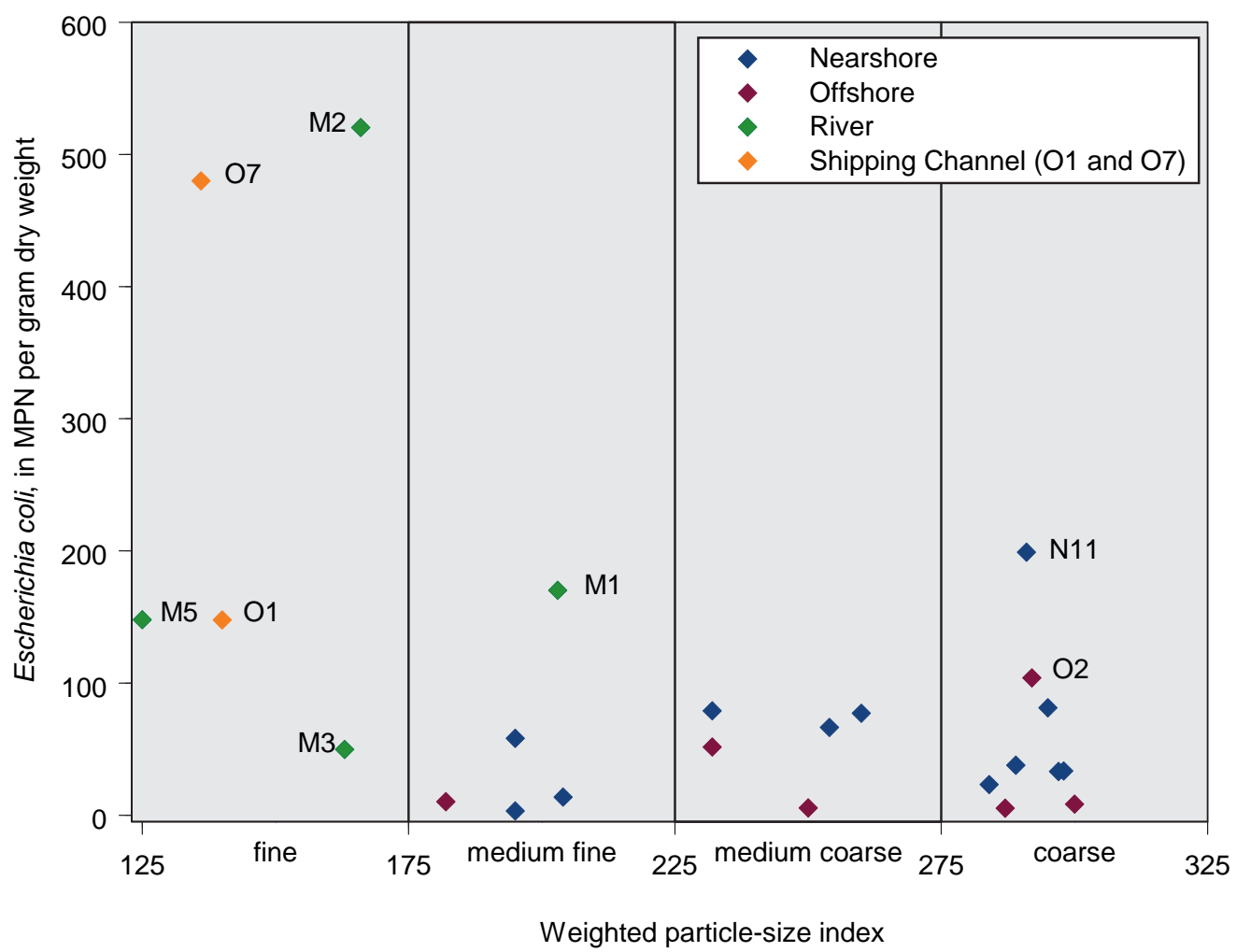

Figure 6. Relation between weighted particle-size index and average $E$. coli concentration at 24 sites, phase 1 (2003). Weighted particle-size index was calculated as (percent clay) $+2 *$ (percent silt) $+3 *$ (percent sand).

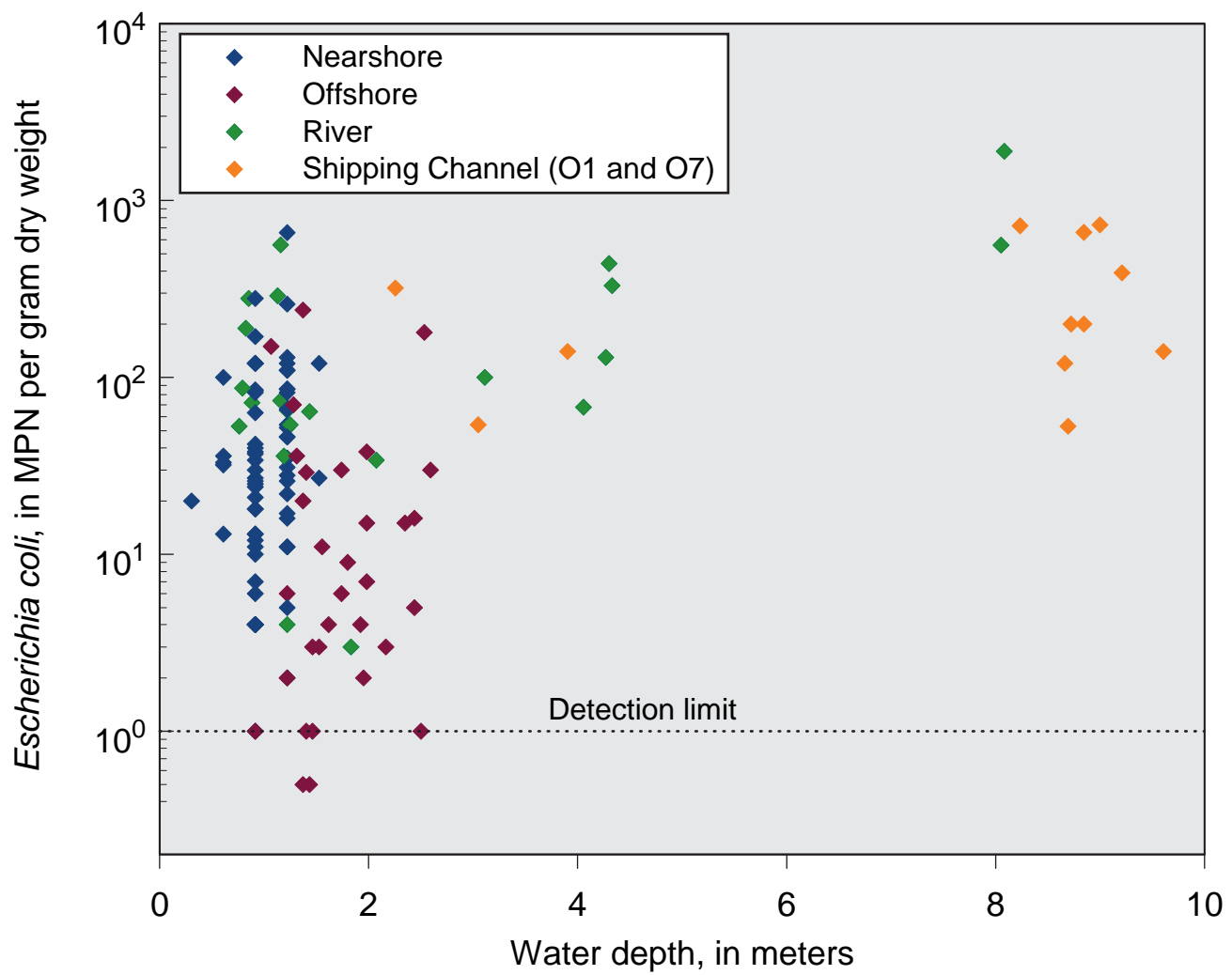

Figure 7. Relation between water depth and concentrations of $E$. coli in bed-sediment samples, phase 1 (2003). 

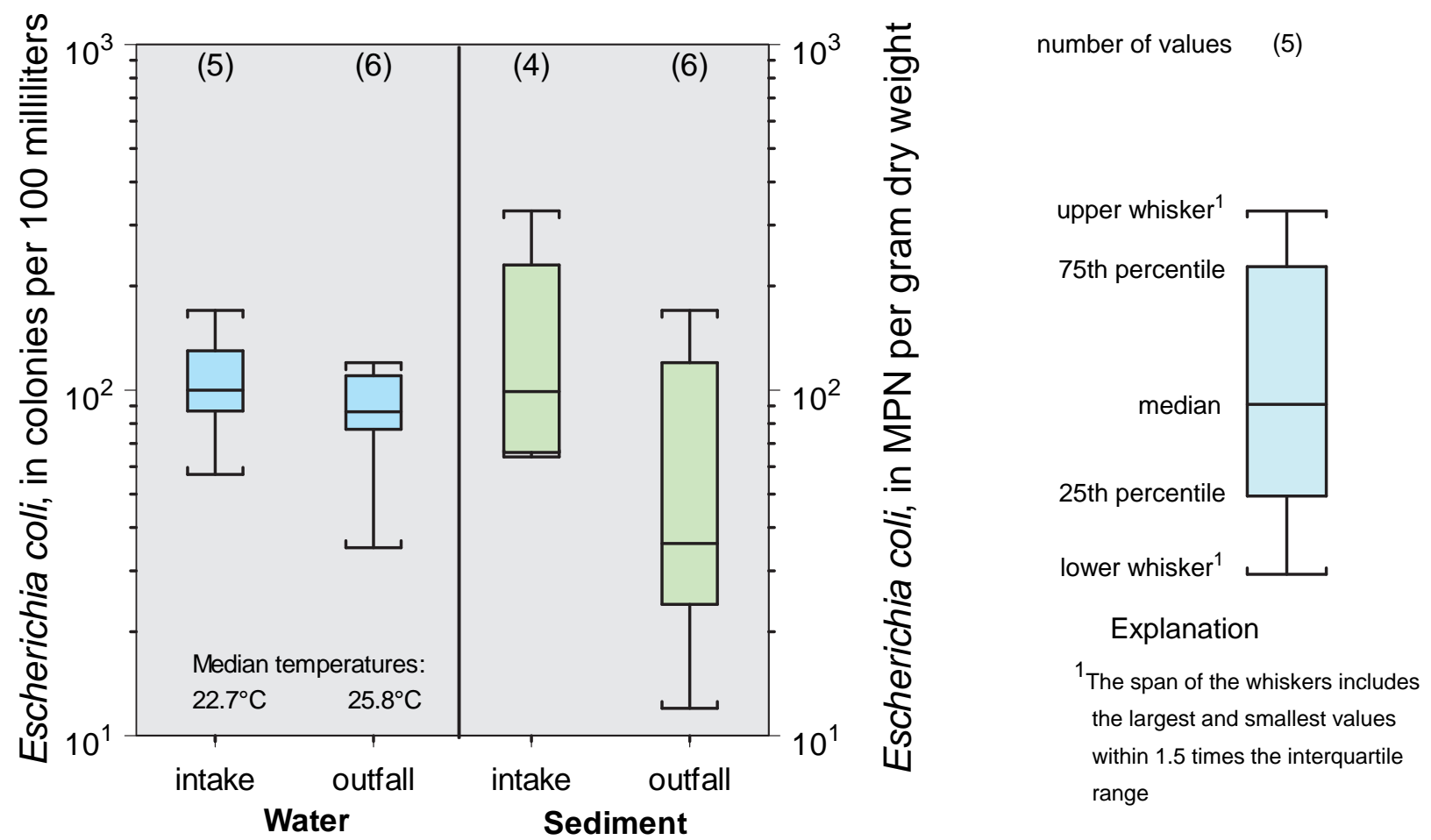

Figure 8. Concentrations of $E$. coli in water and bed sediments and water temperatures in the intake to (M5) and outfall from (N3) the powerplant in synoptic studies, 2003.

surements for each site and associated averages and standard deviations are listed in Appendix 3.

In figure 9a, concentrations of E. coli in water are shown for five sampling days at Maumee River sites in downstream order and at increasing distance offshore from the mouth of the river. Results from site M2 are not included on the graph because M2 is outside of the main channel. Except for the synoptic sampling on May 12, E. coli concentrations in water increased or remained the same downstream from M7 to M2.1 and decreased further offshore in the shipping channel (O9 to O10). Results are not as definitive in the same type of graph for bed sediments (fig. 9b). E. coli concentration peaks were found on some sampling dates at sites M6, M2.1, and O7, and concentrations on four out of five dates were higher at $\mathrm{O} 7$ than at the other two shipping-channel sites (O9 and O10). The water data do not indicate a single, large source of $E$. coli in the sampled segment of the Maumee River; rather, the data indicate that sources of $E$. coli may be distributed throughout this segment and in areas upstream from site M7. The bedsediment data indicate that site $\mathrm{O} 7$ is an E. coli sink; although stream velocity was not measured, it may decrease in the channel at this point.

In figures 10a and 10b, concentrations of E. coli are shown for five sampling days at sites in and around Berger Ditch (fig. 4 inset). Concentrations of E. coli were highest in Berger Ditch (N14) and decreased with increasing distance from Berger Ditch. In sediments, E. coli concentration peaks were found at site N10 on July 13 and August 16. Site N10 is at MBSP, near an old beach ridge where E. coli may become trapped in the bed sediments. Alternatively, an additional source of E. coli may be the beach itself. Insights can be gained from the June 15 sampling, when antecedent 24-hour rainfall was $0.38 \mathrm{~cm}$ and total rainfall for the previous week was the greatest among all the sampling dates-

$6.7 \mathrm{~cm}$. In bed sediments, a peak at site N18 on June 15 may have resulted from sources in Berger Ditch or from the shipping channel. Overall, the data indicate that Berger Ditch is a principal source of $E$. coli to Maumee Bay, that offshore sources are less important, and that N10 and N18 may serve as depositional areas for $E$. coli in bed sediments.

\section{Relations of Water-Quality or Environmental Variables to $E$. coli Concentrations at Maumee Bay State Park During Routine Monitoring}

Statistical tests were done to evaluate quantitatively the relations between environmental or water-quality variables and $E$. coli concentrations in water at MBSP. These relations can be used in future studies to predict when standards will be 


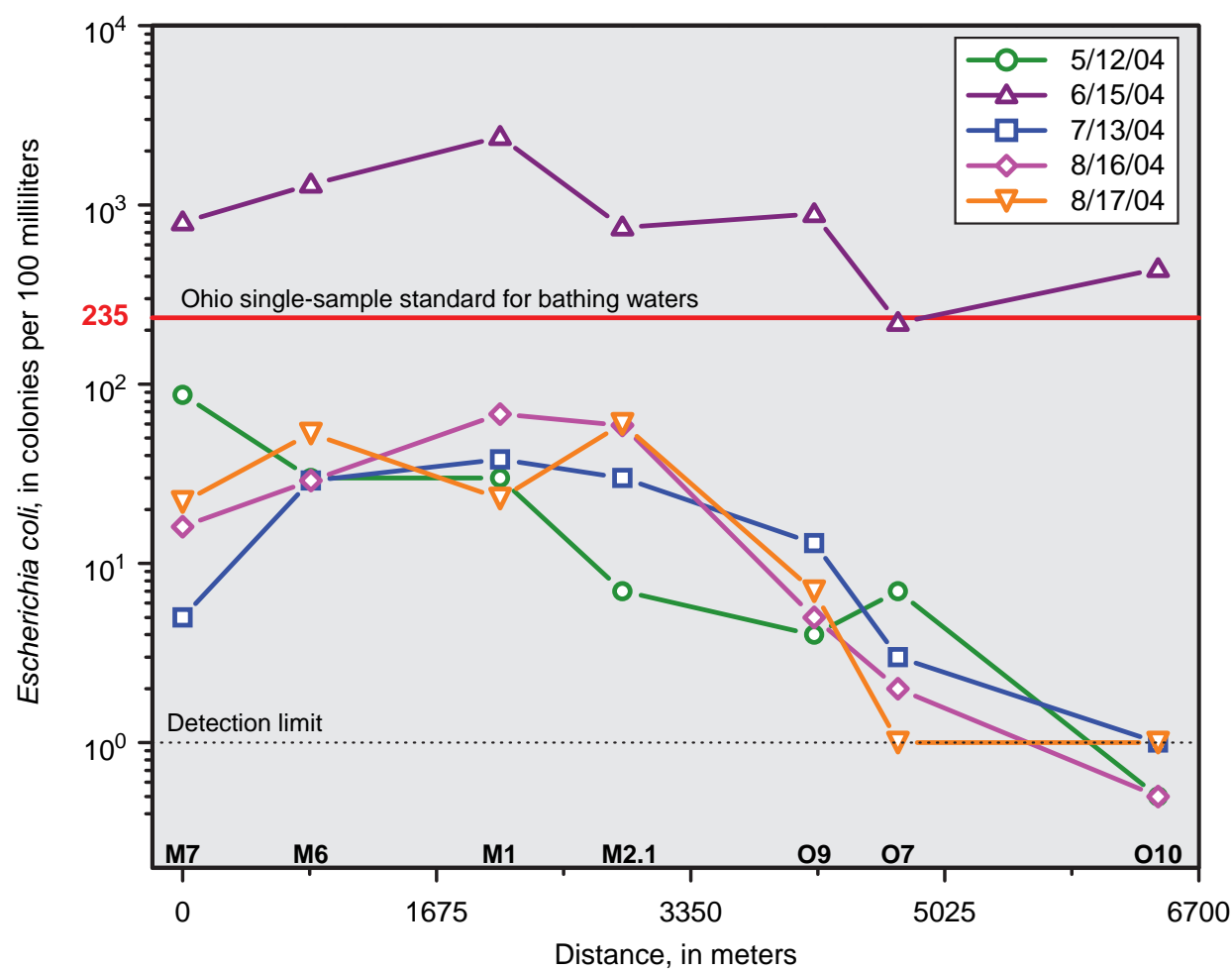

Figure 9A. Concentrations of E. coli in downstream order at Maumee River sites and increasing distance offshore from the mouth of the Maumee River, phase 2 (2004), in water.

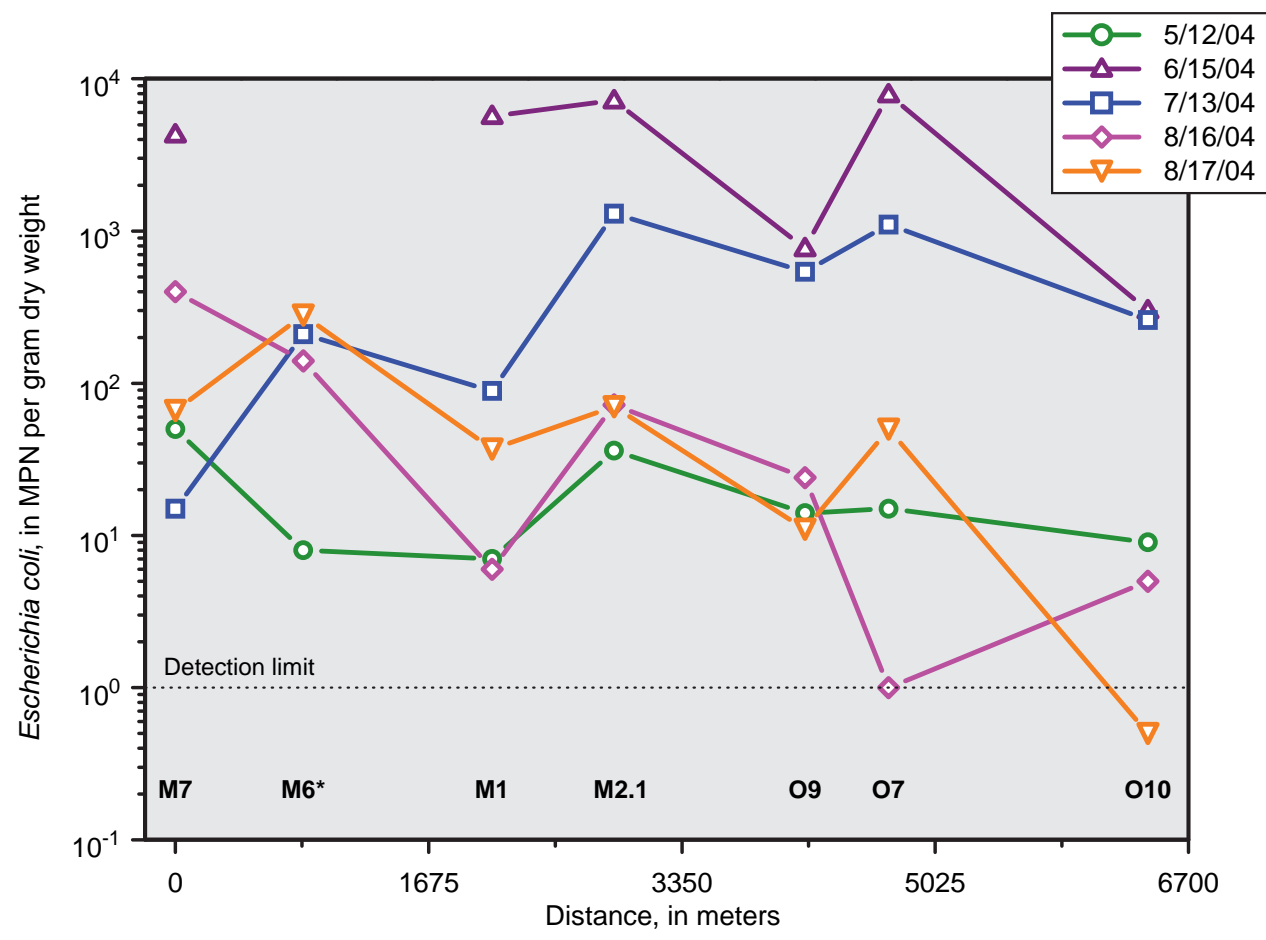

*No sediment sample collected at M6 on 6/15/04

Figure $9 B$. Concentrations of $E$. coli in downstream order at Maumee River sites and increasing distance offshore from the mouth of the Maumee River, phase 2 (2004), in bed sediments. 


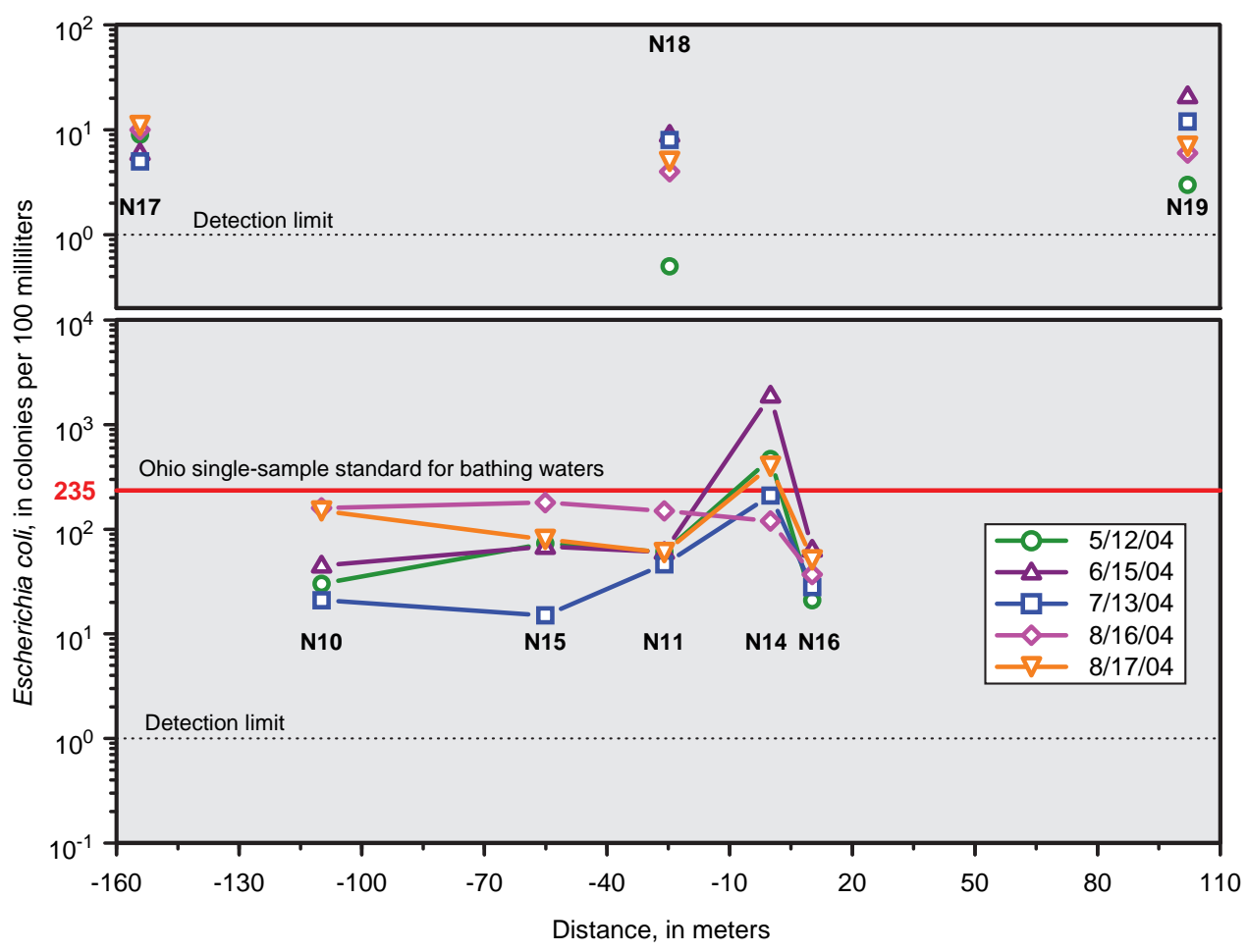

Figure 10A. Concentrations of E. coli at sites in and around Berger Ditch (N14) and in distance from the mouth of Berger Ditch, phase 2 (2004), in water. (Results from the three northern sites (N17, N18, and N19) are shown separately and are not connected by lines to those from the other sites because they are further offshore.)

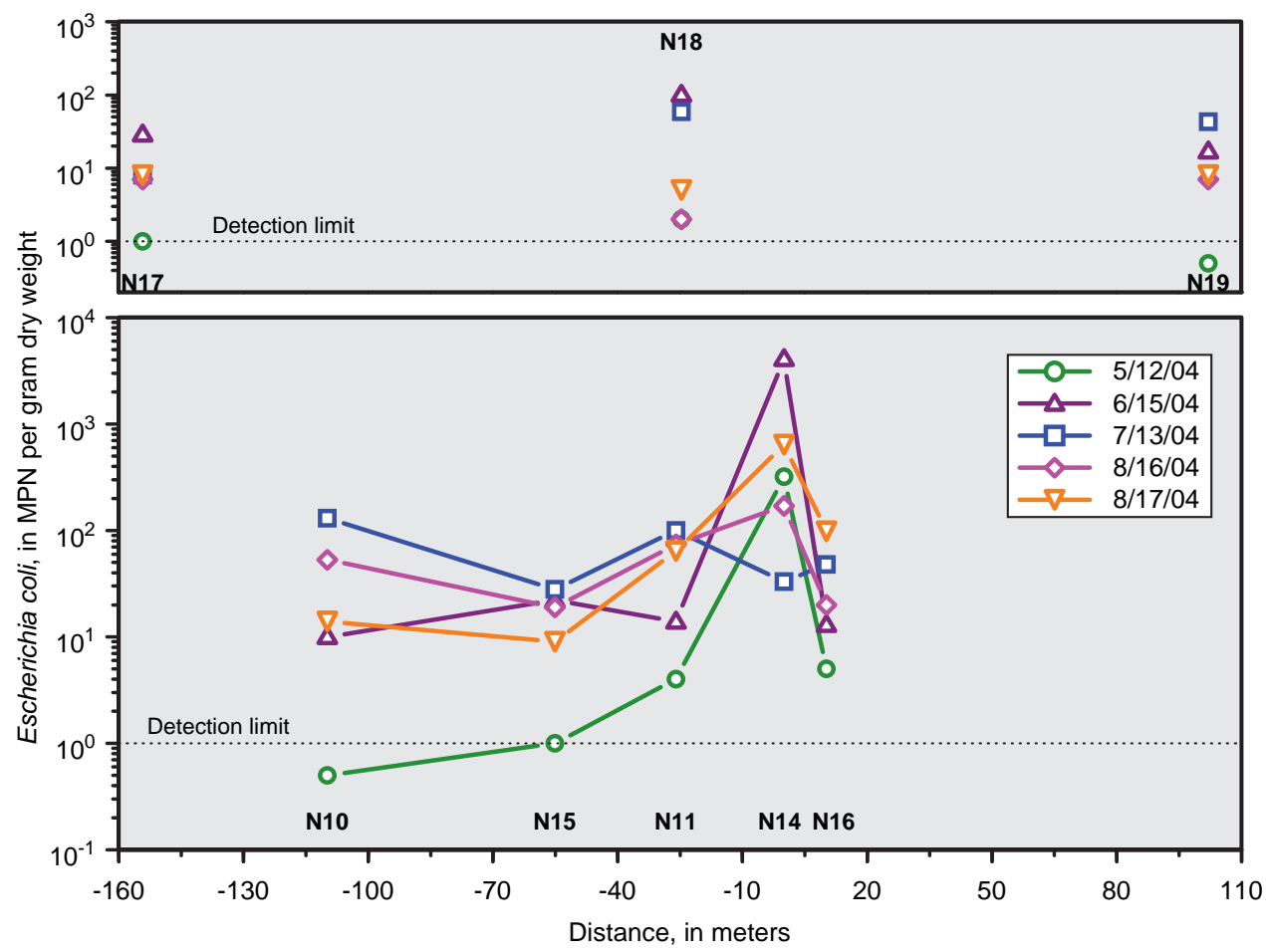

Figure 10B. Concentrations of E. coli at sites in and around Berger Ditch (N14) and in distance from the mouth of Berger Ditch, phase 2 (2004), in bed sediments. (Results from the three northern sites (N17, N18, and N19) are shown separately and are not connected by lines to those from the other sites because they are further offshore.) 
exceeded and the water considered unsafe for recreational use (Francy and others, 2003).

Pearson's $r$ correlation coefficients between $\log _{10}$ E. coli concentrations and continuous variables for 2003, 2004, and the two years combined are listed in table 1 . Several rainfall variables were developed using data from two sources- the City of Oregon ("Rainfall Oregon") and Toledo Metcalf Field ("Rainfall Metcalf"). "Rainfall 24" was the amount of rain that fell in the 24-hour period (10 a.m. to 10 a.m.) preceding the routine sampling. "Rainfall 48 " and "Rainfall 72 " were the amounts of rain that fell in the 24-hour periods 2 days and 3 days, respectively, before the routine sampling. They were used to determine whether there was a lag between rainfall in the watershed and elevated E. coli at MBSP. Among these rainfall variables, only "Rainfall 24 " was significantly related to E. coli, and the "Rainfall Oregon" data showed a stronger relation than the "Rainfall Metcalf" data. "Date" is based on the chronological day of year and the hypothesis that $E$. coli may accumulate over the course of the recreational season; however, "Date" was not significantly related to $E$. coli at MBSP. "Streamflow 7 a.m." is the instantaneous streamflow of the Maumee River at Waterville at 7 a.m. on the day of sampling; "Streamflow mean" is the mean streamflow at this site for the 24-hour period specified. "Streamflow mean today" was weakly related to E. coli in 2003, but not in 2004 . Turbidity was statistically related to $E$. coli for all three datasets. Although "bathers yesterday" was related to E. coli in 2004, no data were compiled for 2003 to confirm this finding.

The relations between E. coli concentrations and two categorical environmental variables - wind direction and wave height-also were examined. E. coli concentrations as a function of wind direction at Oregon at the time of sampling are shown in figure 11. During 2003 and 2004, all E. coli concentrations at MBSP greater than $1,000 \mathrm{MPN} / 100 \mathrm{~mL}$ and 11 out of 15 values in the 235- to 1,000-MPN/100 mL range were associated with wind directions from the north, northeast, or northwest (yellow-shaded areas on fig. 11). (The Ohio single-sample standard for bathing waters is 235). Confirming this qualitative observation, the results of a Wilcoxon ranksum test (Helsel and Hirsch, 1992, p. 118) showed that E. coli concentrations associated with north, northeast, or northwest winds were significantly higher than those associated with winds from all other directions $(\mathrm{p}=0.0049)$. Wave heights at MBSP were placed into three categories based on minimum and maximum heights in each wave train: (1) 0 to $0.6 \mathrm{~m}$, (2) 0.3 to $1 \mathrm{~m}$, and (3) 0.6 to $1.2 \mathrm{~m}$ (fig. 12). Because data were collected by different field personnel and estimated each year in a different manner in 2003 and 2004, the two years were not

Table 1. Pearson's $r$ correlations between log E. coli concentrations in water at Maumee Bay State Park and environmental or water-quality factors, 2003 and 2004.

[The p-value is shown in parentheses; correlations significant at $\alpha<0.05$ are red and bolded; ND, not determined; $<$, less than]

\begin{tabular}{|c|c|c|c|}
\hline Factors & 2003 & 2004 & Combined \\
\hline Rainfall Metcalf $24 \mathrm{hr}$ & $0.33(0.0272)$ & $0.19(0.1718)$ & $0.28(0.0044)$ \\
\hline Rainfall Oregon $24 \mathrm{hr}$ & $0.36(0.0158)$ & $0.44(0.0010)$ & $0.39(<0.0001)$ \\
\hline Rainfall Metcalf $48 \mathrm{hr}$ & $0.25(0.1033)$ & $-0.12(0.3954)$ & $0.08(0.4032)$ \\
\hline Rainfall Oregon $48 \mathrm{hr}$ & $0.10(0.5160)$ & $-0.16(0.2582)$ & $0.02(0.8771)$ \\
\hline Rainfall Metcalf $72 \mathrm{hr}$ & $0.17(0.2745)$ & $-0.08(0.5530)$ & $0.04(0.7150)$ \\
\hline Rainfall Oregon $72 \mathrm{hr}$ & $0.02(0.8961)$ & $-0.02(0.8784)$ & $<0.01(0.9885)$ \\
\hline Date & $-0.14(0.3572)$ & $0.13(0.3590)$ & $-0.02(0.8340)$ \\
\hline Birds today & $0.27(0.1135)$ & $-0.20(0.1481)$ & $0.01(0.8932)$ \\
\hline Bathers today & ND & $-0.34(0.0133)$ & ND \\
\hline Bathers yesterday & ND & $0.35(0.0318)$ & ND \\
\hline Streamflow at 7 a.m. today & $0.28(0.0577)$ & $0.08(0.5623)$ & $0.17(0.0963)$ \\
\hline Streamflow (mean) today & $0.30(0.0444)$ & $0.08(0.5497)$ & $0.18(0.0737)$ \\
\hline Streamflow (mean) yesterday & $0.20(0.1858)$ & $0.12(0.3842)$ & $0.15(0.1410)$ \\
\hline Turbidity & $0.50(0.0004)$ & $0.40(0.0062)$ & $0.48(<0.0001)$ \\
\hline Water level & $0.50(0.0004)$ & $0.26(0.0607)$ & $0.18(0.0681)$ \\
\hline Water temperature & $-0.15(0.3171)$ & $-0.14(0.3394)$ & $-0.21(0.0432)$ \\
\hline
\end{tabular}


combined. Median E. coli concentrations generally increased with increasing wave height. The results of an analysis of variance and Tukey's test (Helsel and Hirsch, 1992, p. 157) confirm that in 2003, the E. coli concentrations in the two wave categories were significantly different from each other; in 2004, the two lowest wave-height categories were significantly different from the highest category (fig. 12).

Wind direction may be an influential factor behind the intensity of other variables at MBSP. In our data set, all five rainfall amounts greater than $1.3 \mathrm{~cm}$ and all 14 turbidity values greater than 75 NTU were associated with north, northeast, or northwest winds (data not shown). All five wave heights placed in the highest category in 2003 and all six in 2004 were associated with north, northeast, or northwest winds. However, only about one-half of these elevated rainfall amounts, turbidity values, and wave heights were associated with $E$. coli values greater than $235 \mathrm{MPN} / 100 \mathrm{~mL}$. Further, not all north, northeast, or northwest winds were associated with elevated turbidity, rainfall, wave height, or E. coli concentrations. The interrelations between wind direction, turbidity, rainfall, wave height, and E. coli concentrations are complicated and can only be better understood through use of multivariate statistical techniques, which was beyond the scope of this study.

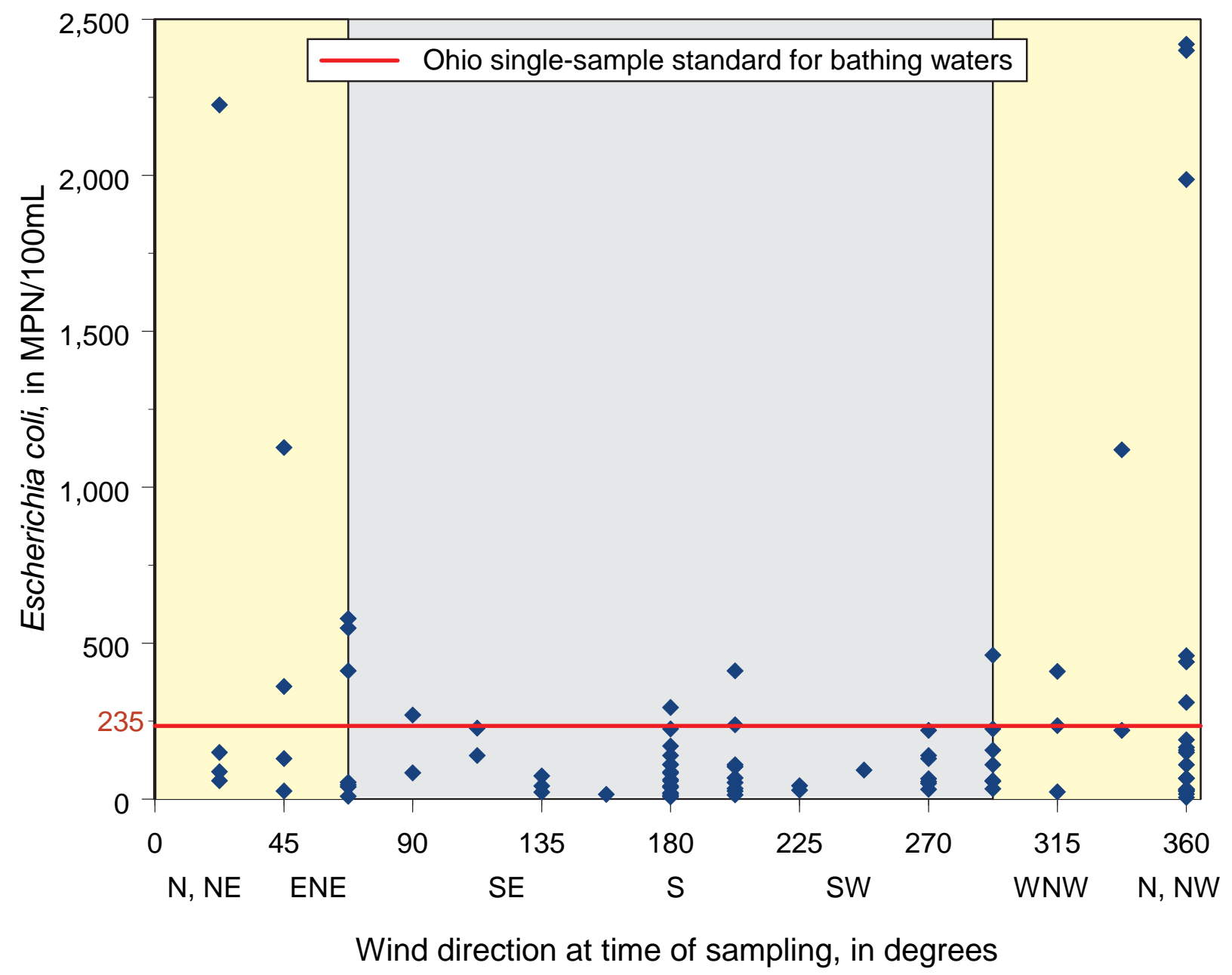

Figure 11. Concentrations of E. coli at Maumee Bay State Park as a function of wind direction at the time of sampling, 2003 and 2004. The yellow-shaded areas indicate winds from north, northeast, or northwest. 


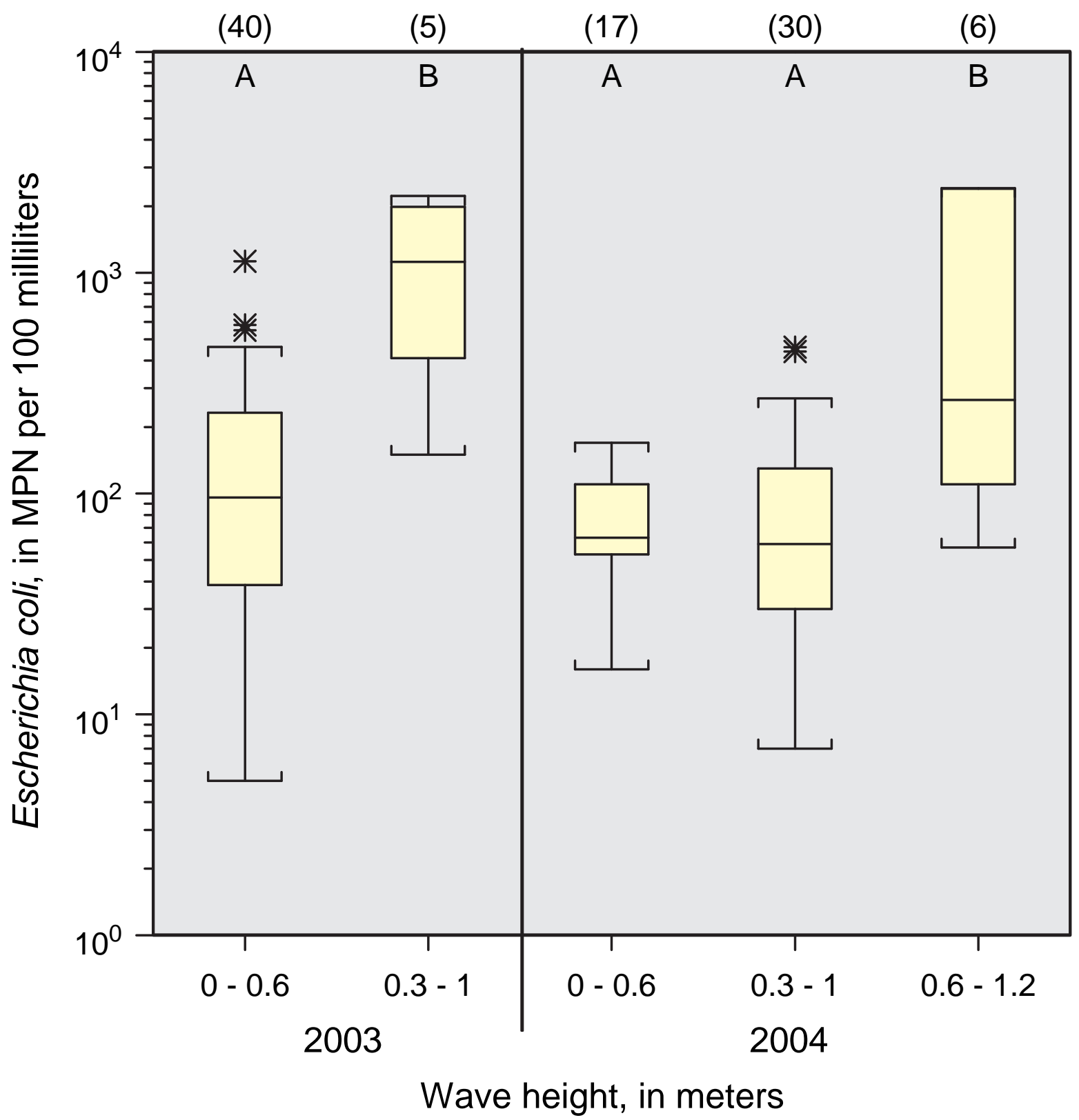

Figure 12. Concentrations of E. coli at Maumee Bay State Park based on wave height at the time of sampling, 2003 and 2004. (Results of Tukey-Kramer multiple comparison test on the $\log _{10}$-transformed data are presented as letters, and medians with a letter in common do not differ significantly at $\alpha=0.05$.) Refer to figure 8 for explanation of boxplots. 


\section{Conclusions}

The U.S. Geological Survey, in cooperation with the Ohio Water Development Authority, Cities of Oregon and Toledo, University of Toledo, and Toledo Metropolitan Area Council of Governments, examined spatial and environmental factors in combination to identify sources of fecal contamination to Maumee Bay, Ohio.

Identifying the factors that showed a relation to $E$. coli can be used to help identify sources and predict when E. coli concentrations are elevated. The strength of the relation between rainfall in the previous 24-hour period and E. coli, and not between rainfall 2 or 3 days before and E. coli, indicates that fecal contamination is most likely of local origin. This was further supported by results showing that Oregon rainfall amounts (collected from a site $1.5 \mathrm{~km}$ inland) were more strongly related to E. coli concentrations than the Metcalf rainfall amounts (collected from a site 16 $\mathrm{km}$ inland). Turbidity and wave height were related to $E$. coli concentrations. This may be because $E$. coli in bed sediments were resuspended into the water column during times of increased wave heights. Wind direction was a good predictor of $E$. coli concentrations - winds from the north, northeast, or northwest resulted in the highest $E$. coli concentrations. Winds from these directions could cause fecal contamination from local sources such as Berger Ditch to remain in the nearshore shallow areas; in contrast, southerly winds would provide a mechanism for transporting fecal contamination out to the open lake.

The two-phased approach to spatial sampling that was used in this study-identifying hot spots of E. coli in water and bed sediments and focusing additional sampling efforts around them-is a useful approach that helps further the understanding of fecal-contaminant sources in a study area. Low E. coli concentrations at sites north and west of the shipping channel indicated that remote sources were not important contributors of E. coli. Although fecal contamination may originate from multiple sources in and around MBSP, elevated E. coli concentrations in Berger Ditch and spatial patterns around the mouth of Berger Ditch indicated that Berger Ditch is a principal source. In addition, E. coli may be originating from the beach itself. High levels of $E$. coli were often associated with bed sediments collected from the deepest waters (and with the smallest particle sizes) including the shipping channel, which may act as an E. coli sink. Heated effluent from a nearby powerplant did not result in elevated $E$. coli concentrations, as was previously suspected.

The next step would be to develop an understanding of the influence of Berger Ditch on E. coli concentrations in Maumee Bay and at MBSP. This could be done by computing $E$. coli loads in Berger Ditch and relating the loads to concentrations of $E$. coli at MBSP. These data could also be used to determine the quantity of water released into Maumee Bay from Berger Ditch, which could then be used by resource managers to implement remediation measures. For example, it has been proposed that a wetland be created near MBSP and that flow from Berger Ditch be diverted into the wetland to naturally treat entrained fecal contaminants.

Although the spatial and environmental data collected during this study do not definitively identify sources of fecal contamination, they do provide sufficient indirect evidence for narrowing the search to proximate sources. This approach can be used as a precursor to more expensive and widely used microbial-source-tracking techniques. A similar spatial, multivariable approach should enable water-resource managers who work in hydrologically complicated areas to target contaminant-source investigations to specific areas, thereby making the best use of available time and resources for diagnosis and remediation of fecal contamination.

\section{Acknowledgments}

The authors thank Chris Kephart and Austin Smith from the USGS, Joshua Saunders, Kris Barnswell, Jona Scarbro, Joseph Hickey, and Colin de Saint Victor from the University of Toledo, who braved the cold water or waves to collect samples. Jeffrey Savino and Patricia Uzmann, University of Toledo, provided invaluable assistance by taking care of the boats and other equipment and helping with the day-to-day operations at the Lake Erie Center. Robert Martin graciously provided us with weather data from the City of Oregon. We also acknowledge assistance from the members of the Maumee Bay Bacteria Task Force in providing valuable input on project planning and data analysis.

\section{References Cited}

Boehm, A.B., Fuhrman, J.A., Mrše, R.D., and Grant, S. B., 2003, Tiered approach for identification of a human fecal pollution source at a recreational beach-Case study at Avalon Bay, Catalina Island, California: Environmental Science \& Technology v. 37, no. 4, p. 673-680.

Burton, G.A., Jr., Gunnison, D., and Lanza, G.R., 1987, Survival of pathogenic bacteria in various freshwater sediments: Applied and Environmental Microbiology, v. 53, no. 4, p. 633-638.

Byappanahalli, M., Fowler, M., Shively, D., and Whitman, R., 2003, Ubiquity and persistence of Escherichia coli in a Midwestern coastal stream: Applied and Environmental Microbiology: v. 69, no. 8, p. 4549-4555.

Francy, D.S., and Darner, R.A. 1998, Factors affecting Escherichia coli concentrations at Lake Erie public bathing beaches: U.S. Geological Survey Water-Resources Investigations Report 98-4241, 41 p. 
Francy, D.S., Gifford, A.M., and Darner, R.A., 2003, Escherichia coli at Ohio bathing beaches-Distribution, sources, wastewater indicators, and predictive modeling: U.S. Geological Survey Water-Resources Investigations Report 02-4285, 120 p.

Glatzer, L., and Erichsen, K., 2003, Wolf Creek bacterial impacts on Maumee Bay State Park Beach, summary report: Bowling Green, Ohio, Maumee RAP Publications, 10 p., accessed March 2005 at http://www.epa.state.oh.us/dsw/rap/ maupub.html

Great Lakes Dredging Team, 1999, Case study series-The Port of Toledo and the Maumee River Basin, accessed March 2005 at http://www.glc.org/dredging/case/toledo. html

Guy, H.P. 1969, Laboratory theory and methods for sediment analysis: U.S. Geological Survey Techniques of WaterResources Investigations, book 5, chap. C1, 58 p.

Hach Company, 1989, Water analysis handbook: Loveland, Colo., p. 589.

Helsel, D.R. and Hirsch, R.M., 1992, Statistical methods in water resources: New York, Elsevier Science Publishing Company [variously paged].

LaLiberte, P., and Grimes, D.J. 1982, Survival of Escherichia coli in lake bottom sediment: Applied and Environmental Microbiology, v. 43, no. 3, p. 623-628.

National Oceanic and Atmospheric Administration, 2004a, National Virtual Data System-National Climatic Data Center: Asheville, N.C., accessed September 2003 and 2004 at http://nndc.noaa.gov/

National Oceanic and Atmospheric Administration, 2004b, International Great Lakes Datum, Center for Operational Oceanographic Products and Services, accessed September 2004 at http://www.co-ops.nos.noaa.gov/

Natural Resources Defense Council, 2004, Testing the waters-A guide to water quality at vacation beaches: New York, $231 \mathrm{p}$.

Ohio Department of Health, 2004, Bathing beach monitoring program, accessed September 2004 at http://www.odh.state. oh.us/odhPrograms/eh/bbeach/beachmon.aspx

Ohio Environmental Protection Agency, 2002, Water use definitions and statewide criteria: Ohio Administrative Code, chap. 3745-1-07, p. 9 and 26.

Shindel, H.L., Mangus, J.P., and Trimble, L.E., 2002, Water resources data, Ohio, water year 2001, volume 2: U.S. Geological Survey Water Data Report $\mathrm{OH}-01-2$, p. xiv.
Shindel, H.L., Mangus, J.P., and Frum, S.R., 2004, Water resources data, Ohio, water year 2003, volume 2: U.S. Geological Survey Water Data Report OH-03-2, p. 260-271.

Shindel, H.L., Mangus, J.P., and Frum, S.R., 2005, Water resources data, Ohio, water year 2004, volume 2: U.S. Geological Survey Water Data Report OH-04-2, p. 284-295.

Stamford, Connecticut, City of, 2001, Non-point sources of bacteria at the beaches, accessed March 2005 at $h t t p: / / w w w$. cityofstamford.org/healthdepartmentlab/PDF/BeachBac8Yr. $p d f$

Stevens, H.H., and Hubbell, D.W., 1986, Computer programs for computing particle-size statistics of fluvial sediments: U.S. Geological Survey Water-Resources Investigations Report 86-4141, 71 p.

U.S. Congress, 2000, Beaches Environmental Assessment and Coastal Health Act of 2000: Washington, D.C., 106th Congress, Public Law 106-284, 9 p.

U.S. Environmental Protection Agency, 2002, Method 1603-Escherichia coli in water by membrane filtration using modified membrane-thermotolerant Escherichia coli agar: Washington, D.C., EPA 821-R-02-023, 9 p. 
Appendix 1. Locations of sampling sites, Maumee Bay, Ohio, 2003 and 2004.

\begin{tabular}{|c|c|c|c|c|c|}
\hline \multirow{2}{*}{ Site ID } & \multirow{2}{*}{ Latitude } & \multirow{2}{*}{ Longitude } & \multirow{2}{*}{ Description } & \multicolumn{2}{|c|}{ Sampled } \\
\hline & & & & 2003 & 2004 \\
\hline \multicolumn{6}{|c|}{ Maumee River } \\
\hline M2 & $41^{\circ} 41^{\prime} 49^{\prime \prime}$ & $83^{\circ} 28^{\prime} 00^{\prime \prime}$ & Maumee River near mouth & $\mathrm{x}$ & $\mathrm{x}$ \\
\hline M2.1 & $41^{\circ} 41^{\prime} 44^{\prime \prime}$ & $83^{\circ} 27^{\prime} 55^{\prime \prime}$ & Maumee River near mouth in shipping channel & & $\mathrm{x}$ \\
\hline M5 & $41^{\circ} 41^{\prime} 40^{\prime \prime}$ & $83^{\circ} 26^{\prime} 27^{\prime \prime}$ & Maumee River near intake Bay Shore Power Plant & $\mathrm{x}$ & \\
\hline M6 & $41^{\circ} 39^{\prime} 24^{\prime \prime}$ & $83^{\circ} 31^{\prime} 12^{\prime \prime}$ & Maumee River downstream of marina & & $\mathrm{x}$ \\
\hline M7 & $41^{\circ} 38^{\prime} 12^{\prime \prime}$ & $83^{\circ} 31^{\prime} 57^{\prime \prime}$ & Maumee River upstream of Anthony Wayne Bridge & & $\mathrm{x}$ \\
\hline \multicolumn{6}{|c|}{ Nearshore } \\
\hline N4 & $41^{\circ} 41^{\prime} 47^{\prime \prime}$ & $83^{\circ} 25^{\prime} 56^{\prime \prime}$ & Maumee Bay near outfall Oregon Wastewater Plant & $\mathrm{x}$ & $\mathrm{x}$ \\
\hline N5 & $41^{\circ} 41^{\prime} 31^{\prime \prime}$ & $83^{\circ} 25^{\prime} 57^{\prime \prime}$ & Maumee Bay near mouth of Heckman Ditch & $\mathrm{x}$ & $\mathrm{x}$ \\
\hline N6 & $41^{\circ} 41^{\prime} 28^{\prime \prime}$ & $83^{\circ} 25^{\prime} 12^{\prime \prime}$ & Maumee Bay near Bayshore & $\mathrm{x}$ & \\
\hline N7 & $41^{\circ} 41^{\prime 2} 27^{\prime \prime}$ & $83^{\circ} 24^{\prime} 38^{\prime \prime}$ & Maumee Bay near mouth of Big Ditch & $\mathrm{x}$ & $\mathrm{x}$ \\
\hline N9 & $41^{\circ} 41^{\prime} 26^{\prime \prime}$ & $83^{\circ} 23^{\prime} 22^{\prime \prime}$ & Maumee Bay near mouth of McHenry Ditch & $\mathrm{x}$ & $\mathrm{x}$ \\
\hline N10 & $41^{\circ} 41^{\prime} 11^{\prime \prime}$ & $83^{\circ} 22^{\prime} 32^{\prime \prime}$ & Maumee Bay at Maumee Bay State Park & $\mathrm{x}$ & $\mathrm{x}$ \\
\hline N11 & $41^{\circ} 41^{\prime} 12^{\prime \prime}$ & $83^{\circ} 22^{\prime} 20^{\prime \prime}$ & Maumee Bay at mouth of Berger Ditch & $\mathrm{x}$ & $\mathrm{x}$ \\
\hline N12 & $41^{\circ} 44^{\prime} 28^{\prime \prime}$ & $83^{\circ} 27^{\prime} 30^{\prime \prime}$ & Ottawa River near mouth & $\mathrm{x}$ & \\
\hline N19 & $41^{\circ} 41^{\prime} 20^{\prime \prime}$ & $83^{\circ} 22^{\prime} 03^{\prime \prime}$ & Maumee Bay northeast of Berger Ditch & & $\mathrm{x}$ \\
\hline \multicolumn{6}{|c|}{ Offshore } \\
\hline $\mathrm{O} 1$ & $41^{\circ} 42^{\prime} 33^{\prime \prime}$ & $83^{\circ} 26^{\prime} 11^{\prime \prime}$ & Maumee Bay near spoil & $\mathrm{x}$ & \\
\hline $\mathrm{O} 2$ & $41^{\circ} 42^{\prime} 59^{\prime \prime}$ & $83^{\circ} 26^{\prime} 03^{\prime \prime}$ & Maumee Bay near shoal & $\mathrm{x}$ & \\
\hline $\mathrm{O} 3$ & $41^{\circ} 44^{\prime} 43^{\prime \prime}$ & $83^{\circ} 25^{\prime} 04^{\prime \prime}$ & Maumee Bay east of Woodtick Peninsula & $\mathrm{x}$ & \\
\hline $\mathrm{O} 4$ & $41^{\circ} 43^{\prime} 34^{\prime \prime}$ & $83^{\circ} 23^{\prime} 28^{\prime \prime}$ & Maumee Bay near shipping channel & $\mathrm{x}$ & \\
\hline O5 & $41^{\circ} 43^{\prime} 34^{\prime \prime}$ & $83^{\circ} 24^{\prime} 01^{\prime \prime}$ & Maumee Bay north of Tobias Ditch & $\mathrm{x}$ & $\mathrm{x}$ \\
\hline O6 & $41^{\circ} 41^{\prime} 33^{\prime \prime}$ & $83^{\circ} 21^{\prime} 09^{\prime \prime}$ & Maumee Bay near mouth of Anderson Ditch & $\mathrm{x}$ & \\
\hline $\mathrm{O} 7$ & $41^{\circ} 43^{\prime} 34^{\prime \prime}$ & $83^{\circ} 24^{\prime} 02^{\prime \prime}$ & Maumee Bay at shipping channel & $\mathrm{x}$ & $\mathrm{x}$ \\
\hline O8 & $41^{\circ} 44^{\prime} 21^{\prime \prime}$ & $83^{\circ} 26^{\prime} 01^{\prime \prime}$ & Maumee Bay southwest of Woodtick Peninsula & $\mathrm{x}$ & \\
\hline O9 & $41^{\circ} 43^{\prime} 06^{\prime \prime}$ & $83^{\circ} 25^{\prime} 10^{\prime \prime}$ & Maumee Bay at shipping channel near mile marker 3 & & $\mathrm{x}$ \\
\hline $\mathrm{O} 10$ & $41^{\circ} 44^{\prime} 27^{\prime \prime}$ & $83^{\circ} 22^{\prime} 14^{\prime \prime}$ & Maumee Bay at shipping channel near mile marker 8 & & $\mathrm{x}$ \\
\hline O11 & $41^{\circ} 42^{\prime} 13^{\prime \prime}$ & $83^{\circ} 24^{\prime} 40^{\prime \prime}$ & Maumee Bay north of Big Ditch & & $\mathrm{x}$ \\
\hline
\end{tabular}


Appendix 2. Concentrations of Escherichia coli (E. coli) in water and bed sediments, 2003.

[E, esimated value; <, less than; $>$, greater than]

\begin{tabular}{|c|c|c|c|c|c|c|c|c|}
\hline \multirow[b]{2}{*}{ Site ID } & \multicolumn{8}{|c|}{ E. coli in water, in colonies per 100 milliliters } \\
\hline & $\begin{array}{c}\text { June } \\
24 \text { or } 25\end{array}$ & $\begin{array}{c}\text { July } \\
29\end{array}$ & $\begin{array}{c}\text { July } \\
30\end{array}$ & $\begin{array}{c}\text { August } \\
14\end{array}$ & $\begin{array}{c}\text { September } \\
7 \\
\end{array}$ & $\begin{array}{c}\text { September } \\
11 \\
\end{array}$ & Average & $\begin{array}{l}\text { Standard } \\
\text { deviation }\end{array}$ \\
\hline M1 & 120 & 250 & 130 & - & 87 & 220 & 160 & 70 \\
\hline M2 & 64 & 200 & 110 & 130 & 100 & 220 & 140 & 61 \\
\hline M3 & E 85 & 180 & 83 & - & 90 & E 57 & 99 & 47 \\
\hline M5 & 57 & 170 & 100 & - & 87 & 130 & 110 & 43 \\
\hline N1 & E 4 & E 11 & E 5 & - & E 12 & $<1$ & 7 & 5 \\
\hline $\mathrm{N} 2$ & E 7 & E 14 & 22 & - & 73 & E 19 & 27 & 26 \\
\hline N3 & 93 & 120 & 35 & - & 110 & 80 & 88 & 33 \\
\hline N4 & E 40 & 200 & 77 & 90 & 82 & E 53 & 90 & 57 \\
\hline N5 & 680 & 97 & E 22 & 23 & E 37 & E 52 & 150 & 260 \\
\hline N6 & $<1$ & 64 & 55 & 240 & 65 & 23 & 75 & 85 \\
\hline N7 & E 61 & 70 & 42 & - & 62 & E 32 & 53 & 16 \\
\hline N9 & 29 & 49 & E 12 & - & E 16 & 21 & 25 & 15 \\
\hline N10 & E 53 & 93 & 22 & - & 130 & E 19 & 63 & 48 \\
\hline N11 & 220 & E 14 & 150 & 24 & 42 & 40 & 82 & 84 \\
\hline N12 & 36 & 40 & E 12 & - & 29 & 53 & 34 & 15 \\
\hline N13 & 80 & 180 & 220 & 87 & 150 & 240 & 160 & 67 \\
\hline $\mathrm{O} 1$ & 33 & 100 & E 51 & 61 & 62 & 68 & 62 & 22 \\
\hline $\mathrm{O} 2$ & E 46 & 72 & 67 & - & 74 & 58 & 63 & 12 \\
\hline $\mathrm{O} 3$ & $<1$ & $<1$ & E 7 & - & E 7 & E 3 & 4 & 3 \\
\hline $\mathrm{O} 4$ & $<1$ & E 9 & E 5 & - & E 13 & E 4 & 6 & 5 \\
\hline O5 & E 7 & E 3 & E 3 & - & E 24 & E 3 & 8 & 9 \\
\hline O6 & 45 & E 2 & E 2 & - & E 5 & E 3 & 11 & 19 \\
\hline $\mathrm{O} 7$ & E 4 & 20 & E 4 & E 13 & 48 & E 5 & 16 & 17 \\
\hline \multirow[t]{2}{*}{$\mathrm{O} 8$} & $<1$ & E 2 & $<1$ & - & E 3 & E 2 & 2 & 1 \\
\hline & \multicolumn{8}{|c|}{ E. coli, in most probable number of colonies per gram dry weight of sediment } \\
\hline \multirow[t]{2}{*}{ Site ID } & June & July & July & August & September & September & Average & Standard \\
\hline & 24 or 25 & 29 & 30 & 14 & 7 & 11 & & deviation \\
\hline M1 & - & 280 & 190 & - & 290 & 87 & 210 & 94 \\
\hline M2 & - & 74 & 65 & 3 & 560 & 1900 & 520 & 800 \\
\hline M3 & 34 & 72 & 53 & - & 36 & 54 & 50 & 16 \\
\hline M5 & - & 130 & 68 & - & 330 & 64 & 150 & 120 \\
\hline N1 & 4 & 13 & 84 & - & 37 & 27 & 33 & 31 \\
\hline $\mathrm{N} 2$ & 2 & 7 & 38 & - & 17 & 5 & 14 & 15 \\
\hline N3 & 46 & 24 & 12 & - & 170 & 26 & 56 & 65 \\
\hline $\mathrm{N} 4$ & 27 & 110 & 66 & 54 & 86 & 120 & 77 & 35 \\
\hline N5 & 18 & 34 & 25 & 13 & 32 & 20 & 24 & 8 \\
\hline N6 & 28 & 280 & 63 & 18 & 52 & 46 & 81 & 99 \\
\hline N7 & 4 & 82 & 42 & - & 13 & 26 & 33 & 31 \\
\hline N9 & 86 & 40 & 35 & - & 30 & 100 & 58 & 32 \\
\hline N10 & 1 & 6 & 4 & - & 4 & 4 & 4 & 2 \\
\hline N11 & 11 & 110 & 120 & 660 & 260 & 33 & 200 & 240 \\
\hline N12 & 11 & 16 & 22 & - & 130 & 10 & 38 & 52 \\
\hline $\mathrm{N} 13$ & 31 & 85 & 120 & 36 & 82 & 120 & 79 & 39 \\
\hline O1 & 200 & 53 & 120 & 54 & 320 & 140 & 150 & 100 \\
\hline $\mathrm{O} 2$ & 30 & 240 & 150 & - & 70 & 29 & 100 & 91 \\
\hline $\mathrm{O} 3$ & 1 & 9 & 6 & - & 11 & 4 & 6 & 4 \\
\hline $\mathrm{O} 4$ & 7 & 15 & 3 & - & 15 & 2 & 8 & 6 \\
\hline O5 & 6 & 30 & 180 & - & 4 & 38 & 52 & 73 \\
\hline O6 & 3 & $<1$ & 1 & - & 36 & 20 & 12 & 16 \\
\hline O7 & $>660$ & 140 & 720 & 200 & 730 & 390 & 470 & 270 \\
\hline $\mathrm{O} 8$ & 16 & 2 & 6 & - & 3 & 1 & 6 & 6 \\
\hline
\end{tabular}


Appendix 3. Concentrations of Escherichia coli (E. coli) in water and bed sediments, 2004.

[E, estimated value; $<$, less than; >, greater than]

\begin{tabular}{|c|c|c|c|c|c|c|c|}
\hline \multirow[b]{2}{*}{ Site ID } & \multicolumn{7}{|c|}{ E. coli in water, in colonies per 100 milliliters } \\
\hline & $\begin{array}{c}\text { May } \\
12 \\
\end{array}$ & $\begin{array}{c}\text { June } \\
15\end{array}$ & $\begin{array}{c}\text { July } \\
13\end{array}$ & $\begin{array}{c}\text { August } \\
16\end{array}$ & $\begin{array}{c}\text { August } \\
17\end{array}$ & Average & $\begin{array}{l}\text { Standard } \\
\text { deviation }\end{array}$ \\
\hline M1 & E 30 & 2400 & 38 & 68 & 23 & 510 & 1000 \\
\hline M2 & E 25 & 730 & E 26 & 45 & 120 & 190 & 300 \\
\hline M2.1 & E 7 & 750 & E 30 & 59 & 60 & 180 & 320 \\
\hline M6 & E 30 & 1300 & 29 & 29 & 53 & 290 & 570 \\
\hline M7 & 87 & 800 & E 5 & E 16 & 22 & 190 & 340 \\
\hline N4 & E 32 & 440 & 30 & 120 & 38 & 130 & 180 \\
\hline N5 & E 19 & 200 & 6 & E 14 & E 18 & 51 & 83 \\
\hline N7 & E 12 & 220 & E 5 & 23 & E 13 & 55 & 93 \\
\hline N9 & E 40 & E 15 & 20 & 25 & E 8 & 22 & 12 \\
\hline N10 & E 30 & 45 & E 21 & 160 & 150 & 81 & 68 \\
\hline N11 & E 61 & 61 & 46 & 150 & 60 & 76 & 42 \\
\hline N14 & 470 & 1900 & E 210 & 120 & 400 & 620 & 730 \\
\hline N15 & 73 & 68 & E 15 & 180 & 80 & 83 & 60 \\
\hline N16 & E 21 & 64 & 28 & 37 & 51 & 40 & 17 \\
\hline N17 & E 9 & E 6 & E 5 & E 10 & E 11 & 8 & 3 \\
\hline N18 & $<3$ & E 9 & E 8 & E 4 & E 5 & 6 & 3 \\
\hline N19 & E 3 & 21 & E 12 & E 6 & E 7 & 10 & 7 \\
\hline O5 & $<1$ & 45 & $<1$ & $<1$ & E 1 & 10 & 20 \\
\hline O7 & E 7 & E 220 & E 3 & E 2 & E 1 & 47 & 97 \\
\hline O9 & E 4 & E 890 & E 13 & E 5 & E 7 & 180 & 400 \\
\hline $\mathrm{O} 10$ & $<1$ & E 440 & E 1 & $<1$ & E 1 & 89 & 200 \\
\hline \multirow[t]{2}{*}{ O11 } & E 5 & 28 & E 8 & 67 & 43 & 30 & 26 \\
\hline & \multicolumn{7}{|c|}{ E. coli, in most probable number of colonies per gram dry weight of sediment } \\
\hline \multirow[t]{2}{*}{ Site ID } & May & June & July & August & August & Average & Standard \\
\hline & 12 & 15 & 13 & & & & deviation \\
\hline M1 & 7 & 5700 & 88 & 6 & 37 & 1200 & 2500 \\
\hline M2 & 13 & 1200 & 94 & 8 & 130 & 290 & 510 \\
\hline M2.1 & 36 & $>7200$ & 1300 & 72 & 70 & 1700 & 3100 \\
\hline M6 & 8 & & 210 & 140 & 280 & 160 & 120 \\
\hline M7 & 50 & 4300 & 15 & 400 & 66 & 970 & 1900 \\
\hline $\mathrm{N} 4$ & 53 & 240 & 26 & 66 & $>350$ & 150 & 140 \\
\hline N5 & 2 & 42 & 28 & 15 & 17 & 21 & 15 \\
\hline N7 & 1 & 35 & 11 & 23 & 16 & 17 & 13 \\
\hline N9 & 4 & 25 & 34 & 12 & 270 & 69 & 110 \\
\hline N10 & $<1$ & 10 & 130 & 53 & 14 & 42 & 53 \\
\hline N11 & 4 & 14 & 100 & 74 & 64 & 51 & 41 \\
\hline N14 & 320 & $>4100$ & 32 & 170 & 640 & 1000 & 1700 \\
\hline N15 & 1 & 22 & 28 & 19 & 9 & 16 & 11 \\
\hline N16 & 5 & 12 & 48 & 20 & 98 & 37 & 38 \\
\hline N17 & 1 & 29 & 8 & 7 & 8 & 11 & 11 \\
\hline N18 & 2 & 100 & 59 & 2 & 5 & 34 & 44 \\
\hline N19 & $<1$ & 17 & 43 & 7 & 8 & 15 & 16 \\
\hline $\mathrm{O} 5$ & $<1$ & 91 & 21 & 4 & 1 & 24 & 38 \\
\hline $\mathrm{O} 7$ & 15 & $>7900$ & 1100 & 1 & 50 & 1800 & 3400 \\
\hline O9 & 14 & $>770$ & 540 & 24 & 11 & 270 & 360 \\
\hline $\mathrm{O} 10$ & 9 & 300 & 260 & 5 & $<1$ & 120 & 150 \\
\hline O11 & 2 & 13 & 19 & 64 & 13 & 22 & 24 \\
\hline
\end{tabular}

